Article

\title{
Sustainable-Development Measurement of China's Coworking Industry Using Social-Network Analysis Method
}

\author{
Danning Zhang ${ }^{1, *}$, Ming Yan ${ }^{1}$, Haowen Wang ${ }^{1}$ and Weiwei $\mathrm{Li}^{2, *}$ (D) \\ 1 School of Economics, Liaoning University, Shenyang 110136, China; yuming2017618@163.com (M.Y.); \\ whw15993962985@163.com (H.W.) \\ 2 School of Business Administration, Northeastern University, Shenyang 110167, China \\ * Correspondence: katherinezdn@126.com (D.Z.); liww@mail.neu.edu.cn (W.L.); \\ Tel.: +86-24-8624-1307 (D.Z. \& W.L.)
}

Citation: Zhang, D.; Yan, M.; Wang, H.; Li, W. Sustainable-Development Measurement of China's Coworking Industry Using Social-Network Analysis Method. Sustainability 2021, 13, 5902. https://doi.org/10.3390/ su13115902

Academic Editor: Fernando Almeida

Received: 3 April 2021

Accepted: 17 May 2021

Published: 24 May 2021

Publisher's Note: MDPI stays neutral with regard to jurisdictional claims in published maps and institutional affiliations.

Copyright: (c) 2021 by the authors. Licensee MDPI, Basel, Switzerland. This article is an open access article distributed under the terms and conditions of the Creative Commons Attribution (CC BY) license (https:// creativecommons.org/licenses/by/ $4.0 /)$.
Abstract: While China's sharing economy slows down and enters a period of structural adjustment, the coworking industry is a new force. Moreover, after China had issued important policies to support the comprehensive upgrading and the sustainable development of mass entrepreneurship and mass innovation in September 2018, the development potential of the coworking industry became even greater. However, the coworking industry also faces many development bottlenecks, such as the homogeneity of services and the single-profit model. Therefore, it is of great theoretical and practical significance to realize the sustainable development of the coworking industry to facilitate mass entrepreneurship and innovation in China. The coworking industry is both a subindustry of sharing economy and a branch of the Internet industry, with the significant characteristic of networking. Therefore, we used social-network analysis (SNA) to build a three-level index system of China's coworking industry: the density-comprehensive index at the macrolevel, the subgroup comprehensive index at the mesolevel, and the centrality-comprehensive index at the microlevel, so as to scientifically measure the development status of the coworking industry. In addition, the comprehensive index system was applied to a comparative study of the six models that were formed in actual development. Analytical results indicate that China coworking industry formed a good network with rich ecological diversity. Different from other countries, China's coworking industry has embodied a profound gene of entrepreneurship and innovation since its early stage of development. Internet giant enterprises Alibaba, Tencent, and Baidu are playing an important role in the development of China's coworking industry, and all have strategic layouts among several models.

Keywords: sustainability; coworking industry; mass entrepreneurship and mass innovation; socialnetwork analysis; comprehensive index system

\section{Introduction}

After China put forward the strategy of mass entrepreneurship and mass innovation in 2015, the State Council issued important policies to support the comprehensive upgrade and sustainable development of mass entrepreneurship and mass innovation in September 2018, which brought new opportunities for China's coworking industry and enhanced the role of the industry to promote the incubation and growth of small and microbusinesses [1,2]. Coworking industry is a branch of the sharing economy that is characterized by providing services and revenue at a marginal cost below that of professional organizers in order to share idle resources through social platforms [3-6]. After growth and expansion, the development of China's sharing economy, represented by the sharing-mobility and sharing-accommodation industries, significantly slowed down, and entered the turning point of a deep adjustment period [7]. However, in sharp contrast, the coworking industry emerged, which subverted and challenged the traditional office model represented by commercial office buildings. Generations after the 1980s and 1990s in China are the mainstream of entrepreneurs, so coworking spaces with a smaller scale, richer retail 
formats, and more convenient transportation are more favored. According to statistics, the coworking industry could reduce office costs by $30 \%$ in first-tier cities such as Beijing, Shanghai, and Guangzhou, greatly reducing the cost of innovation and entrepreneurship. By the end of September 2018, there were more than 300 platforms of China's coworking operators, more than 6000 outlets, 12 million square meters of total operation area, and 2 million stations. It was estimated that, by 2020, the number of China's coworking spaces would reach 5000, and the market size of the industry would reach CNY 231.5 billion [8]. However, compared with the foreign coworking industry, which originated in a mature entrepreneurial atmosphere, there are still some bottlenecks in the sustainable development of China's coworking industry, such as the single-profit model, product homogeneity, and intense competition [9-12]. Therefore, how to promote the high-quality development of the coworking industry while upgrading mass entrepreneurship and mass innovation in China is of great theoretical and practical significance. So, on the basis of clarifying the development status of China's coworking industry, the paper aims at how to break through the development bottleneck and realize the sustainable development of the industry, so as to facilitate upgrading China's mass entrepreneurship and innovation.

So far, scholars carried out extensive and indepth explorations on the coworking industry from various aspects. First, the case study of successful coworking office spaces such as Youke Workshop, WeWork, and Venture Café was a main research direction. Scholars studied the concept, design principles, and strategies of coworking spaces, and some scholars studied their relationship with the design of coworking space in combination with the background of industrial transformation and entrepreneurship [13-19]. Another research direction is the construction of the business model of coworking industry, focusing on analyzing business model elements, including the profit model, and positioning and business system. The study found that the business model of coworking spaces has diversity, but the current business model is not mature, and profit is one of the main difficulties faced by the coworking industry. Scholars believe that, to resolve that dilemma, we should speed up the asset light of capital, create new business forms of smart offices, increase value-added services, and explore diversified business models [20-26]. Many scholars also paid attention to the research on the mechanism of the coworking industry to promote enterprise innovation. The spatial creativity of coworking is positively correlated with the business model, the business model should focus on innovation, and the growth strategy should focus on the direction of platform and community. Some scholars took coworking office spaces as a Schelling point, which is an effective organizational carrier to significantly promote the innovation and entrepreneurship of small and microenterprises. Enterprises can reasonably allocate and utilize idle effective resources, improve the efficiency of resource utilization, and maximize the utilization of resources by coordinating the necessary talents, funds, information, and other resources [11,27]. An increasing number of studies show that the coworking industry is subindustry of both the sharing economy and the Internet industry, with a significant characteristic of networking. Therefore, the introduction of the network-organization perspective has opened up a new direction for research on the coworking industry [28-31].

A widely accepted approach to study the network organization of an industry is the theory of social-network analysis (SNA), which provides analytical thinking for coordinated symbiosis, and properly describes the complex and diverse social interaction of systemlike industries [32-36]. SNA contains a systematic framework and analytical methods in many interdisciplinary studies, especially in economics and management. It provides a new viewpoint of network structure, and builds a bridge between micronetwork subjects (individual behavior) and macronetwork structures (whole network phenomenon) [37]. Due to typical "Internet Plus" characteristics, the coworking industry presents a trend of cross-border integration. Different types of enterprises and organizations, such as start-up enterprises, real estate companies, Internet platform enterprises, and investment and financing institutions have formed a close network relationship. In this network, there are individual decision making and the operation of microenterprises and organizations, and also collaborative 
cooperation between different enterprises and organizations on the macrolevel. Therefore, SNA has good applicability to the study on the coworking industry, especially to explore structural network characteristics. Therefore, we used SNA to build a three-level index system of China's coworking industry: the density-comprehensive index on the macrolevel, subgroup-comprehensive index on the mesolevel, and centrality-comprehensive index on the microlevel, so as to scientifically measure the development status of the coworking industry. In addition, China's coworking industry shows a significant feature of model diversification, which was ignored in existing studies. Therefore, the comprehensive-index system was applied to the comparative study of six models that formed in actual development in order to put forward the targeted countermeasures for the sustainable development of the coworking industry [8].

The rest of the paper is organized as follows. Section 2 provides a brief introduction of the study case. Section 3 constructs the three-level index system on the basis of SNA theory. Results and analysis are shown in Section 4. Conclusions, suggestions, and future works are outlined in Section 5.

\section{Study Cases}

The customers of China's coworking include small and medium-sized enterprises, branches of large enterprises, and start-up companies, among which small and mediumsized enterprises are the main service groups. During 2016-2019, the overall scale of China's coworking market annually increased, but the growth rate slowed down. From 2019 to 2020, China's coworking industry experienced a low ebb, but the consumption upgrading trend of China's office market still exists. In 2020, the market scale of China's coworking industry exceeded CNY 130 billion, and it is expected that the scale will reach CNY 227.35 billion in 2022. In terms of industrial layout, the cities of Beijing, Shanghai, Guangzhou, and Shenzhen are the headquarters of China's coworking industry. The diversification of development modes is a prominent feature of China's coworking industry. According to different operation mechanisms, China's coworking industry formed six development models: the media-platform, large-leading-enterprise, new real-estate, openspace, industry-driven, and angel-investment models, bearing the responsibility to support the development of start-ups [8,38,39].

(1) Media-platform model: relies on a powerful media platform that uses industry resources, cutting-edge information; a network platform to provide support to entrepreneurs by using the experience accumulated from long-term follow-up reports on the entrepreneurial environment. In this model, the incubator uses a huge media platform to help the incubation project improve its reputation and capital docking ability.

(2) Large-leading-enterprise model: mainly relies on powerful large enterprises. With their strong financial and technical ability, and professional mentors for entrepreneurship training, large enterprises provide entrepreneurs with efficient and convenient innovation and entrepreneurship services. After growing, incubated enterprises can enter the supply chain network of large enterprises, and achieve innovation feedback by becoming new entrepreneurship mentors, further promoting the development of the coworking space.

(3) New real-estate model: leading institutions of this model are generally large realestate developers. The most significant characteristics of this model are flexible leasing space and the open entrepreneurial environment, which reduces one-time leasing areas and deducts the conventional leasing cycle. The obvious disadvantage is the single-profit model by only charging for renting space.

(4) Open-space model. This model mainly provides basic office space and equipment, charges low rent in order to reduce the threshold of office work and entrepreneurs, holds rich activities such as entrepreneurship salons, and gathers abundant Internet resources to accelerate the empowerment of small and medium-sized enterprises.

(5) Industry-driven model. This model is led by the government or industrial association. Funded by the government to set up a certain industry guidance funds for directional 
incubation, the model aims at promoting the local regional economic development. Therefore, it has a significant advantage in gathering various industrial resources.

(6) Angel-investment model. This model mainly refers to the successful experience of mature incubators in the United States, Israel, and other countries. Through the introduction of professional mentors, the model provides business-plan guidance and risk-aversion training to improve the success rate of incubation, and provides angel-investment funds to obtain capital dividends after the growth of enterprises.

Brief profiles of these six models are shown in Table 1.

Table 1. Specifications of China's six models of coworking industry.

\begin{tabular}{|c|c|c|}
\hline Model & Business Features & Representative \\
\hline Media platform & $\begin{array}{c}\text { Core resource: powerful media platform } \\
\text { Advantages: improvement in reputation and } \\
\text { capital-docking ability }\end{array}$ & $\begin{array}{c}\text { Kr Space, Demo Space, Toutiao Creation } \\
\text { Space }\end{array}$ \\
\hline Large leading enterprise & $\begin{array}{c}\text { Core resource: large enterprises with strong } \\
\text { financial and technological resources } \\
\text { Advantages: enter supply-chain network of large } \\
\text { enterprises. } \\
\text { Core resource: large real-estate developers }\end{array}$ & $\begin{array}{c}\mathrm{HCH}, \\
\text { Baidu Developer Entrepreneurship Center }\end{array}$ \\
\hline New real estate & $\begin{array}{c}\text { Advantages: flexible leasing space and open } \\
\text { entrepreneurial environment }\end{array}$ & Daydayup, SOHO 3Q \\
\hline Open space & $\begin{array}{l}\text { Core resource: basic office space and equipment } \\
\text { Advantages: low rent }\end{array}$ & Garage Cafe, Innospace \\
\hline Industry-driven & $\begin{array}{l}\text { Core resource: government or industrial } \\
\text { association } \\
\text { Advantages: government support and plenty of } \\
\text { industrial resources }\end{array}$ & $\begin{array}{c}\text { Shanghai Zhangjiang Incubator, Shanghai } \\
\text { cloud valley }\end{array}$ \\
\hline Angel investment & $\begin{array}{c}\text { Core resource: angel investment } \\
\text { Advantages: specialized entrepreneurial services } \\
\text { and financial support }\end{array}$ & Sinovation Ventures, TusStar \\
\hline
\end{tabular}

\section{Methods}

Due to the existence of synergy and cooperation between enterprises and organizations, coworking industry can be regarded as a business ecosystem. Studies showed that factors that affect the operation of business systems can generally be divided into three levels: the macrolevel, referring to the ecological environment; the mesolevel, referring to the ecological subgroup; and the microlevel, referring to ecological niches [40-48]. Because the business ecosystem has the characteristics of network, SNA provides method support for the sustainable development of the coworking industry. Accordingly, a comprehensive index system was constructed to measure the development of China's coworking office industry, including the density-comprehensive index, subgroup comprehensive index, and centrality-comprehensive index based on the combination of SNA and comprehensiveindex theory [49-51]. The data come from two sources. One is industry research reports: the 2018-2019 China Coworking Industry Research Report, Research Report on Coworking Brand in China in 2018, and 2019-2025 Investment Potential Analysis and Future Prospect Forecast Report of China's Coworking Industry [38,39,52]. The other source is Baidu Search. First, nodes of coworking enterprises were determined through the industry research reports. Then, through enterprise websites and Baidu search and according to the existence of cooperation between different types of enterprises, we examined if there was correlation among them. Correlation between different types of enterprises and coworking enterprises is of diversity. For example, the criterion to judge whether a coworking enterprise and an Internet enterprise cooperate is whether the Internet enterprise provides a network platform for the coworking enterprise to conduct transactions or display products and services. The criterion for the cooperation between coworking enterprises and real-estate companies is that strategic real-estate cooperation agreement is signed between them. The criterion of 
whether a coworking enterprise cooperates with an investment and financing institution is whether the latter funds the coworking enterprise. The criterion of whether a coworking enterprise cooperates with a university or a scientific research institution is whether the latter carries out intelligence consultation or joint research. If there is cooperation among different types of enterprises, the network relationship is marked as 1; otherwise, it is marked as 0 . Considering the equality of cooperative relationships in the development of coworking industry, there is no difference in the weight of network relationships. On that basis, the equal-weight $0-1$ network relation matrix is obtained, the network-structure diagram of each development model can be drawn according to the relation matrix, and the different network-structure characteristics can be calculated and described.

\subsection{Density-Comprehensive Index (Macrolevel)}

In SNA, graph density and centrality are the two most important indicators used to describe the organizational characteristics of the overall network. Let $N$ represent the number of nodes in a network, and $L$ represent the number of connections between nodes in the network. Without loss of generality, for a network $G$, we have $N=\left\{n_{1}, n_{2}, \ldots, n_{n}\right\}$, $L=\left\{l_{1}, l_{2}, \ldots, l_{n}\right\}$. For network $G$, if density is large, this indicates that connections between nodes are closer and resources flow fast. If density is small, it indicates a lack of cooperation in the network, and the limited resource support that each node can obtain. Density is measured by the ratio of the number of connections actually existing in the network to the number of connections that may exist [5,42]. If graph centrality is high, it indicates that hub nodes formed, and there is more cooperation around hub nodes. On the other hand, it indicates that the status of the nodes is relatively equal, and cooperation is relatively dispersed.

Accordingly, the two indicators of graph density and centrality were integrated here into the density-comprehensive index $\left(I_{D}\right)$, so as to characterize the tightness and cohesion of the industrial network. Index $I_{D}$ is calculated by

$$
\left\{\begin{array}{l}
I_{D}=W_{d} \varphi_{1}(\alpha)+W_{c} \varphi_{2}(\beta) \\
\alpha=\frac{2 L}{N(N-1)} \\
\beta=\sum_{i=1}^{n}\left(C_{\max }-C_{i}\right) / \max \left\{\sum_{i=1}^{n}\left(C_{\max }-C_{i}\right)\right\}
\end{array}\right.
$$

where $L$ is the number of connections between nodes, and $N$ is the number of nodes in the network; $\varphi_{1}$ and $\varphi_{2}$ are dimensionless functions. In order to ensure the same threshold value, generally let $\varphi_{1}=\varphi_{2}$, and the $0-1$ extreme value method was used in the paper. $C_{\max }$ is the maximal centrality of each node, and $C_{i}$ is the centrality of Node $i . W_{d}$ is the density weight and $W_{c}$ is the centrality weight of the graph.

\subsection{Subgroup-Comprehensive Index (Mesolevel)}

In the whole network, subgroup clustering can be found according to the density of relations between nodes, and each subgroup clustering is an ego network. On the basis of the subgroup, network relations can be divided into internal links in each subgroup clustering and external links between different subgroup clustering. So, on the basis of clustering social-network theory, the external-internal $(E-I)$ index was used to measure the degree of clustering of a network on the basis of the quantity of subgroups, which is calculated with

$$
E-I=\frac{E L-I L}{E L+I L}
$$

where $E L$ is the number of relationships between subgroups, and $I L$ is the number of relationships in each subgroup. $E-I \in(-1,+1)$ and $E-I$ were close to +1 , indicating a high degree of clustering, and vice versa. 


\subsection{Centrality-Comprehensive Index (Microlevel)}

Centrality indices, including three subindices, are the most commonly used indicators to measure the location and the power of nodes. The first is the point centrality used to measure the power of a node. The second is betweenness centrality, used to measure a node's ability to control resources. The last is closeness centrality, used to measure a node's ability not to be controlled by the others. On this basis, all three indices were integrated as the centrality-comprehensive index (short for $I_{C}$ ) in this paper and calculated by

$$
\left\{\begin{array}{l}
I_{c}=W_{p} \varphi_{1}(\alpha)+W_{b} \varphi_{2}(\beta)+W_{c} \varphi_{3}(\gamma) \\
\alpha=\frac{d\left(n_{j}\right)}{g-1} \\
\beta=\sum_{j=1}^{g} d\left(n_{i}, n_{j}\right) \\
\gamma=\sum_{j \prec k}\left(n_{j}\right) / g_{j k}
\end{array}\right.
$$

where $\varphi_{1}, \varphi_{2}$, and $\varphi_{3}$ are dimensionless functions, and $W_{p}, W_{b}, W_{c}$ represent the weights of point centrality, betweenness centrality, and closeness centrality, respectively; $d\left(n_{i}\right)$ represents the number of network connections actually owned by a node, $g$ represents the number of network nodes, $d\left(n_{i}, n_{j}\right)$ represents the distance between nodes $i$ and $j$, and $g_{j k}$ represents the number of shortcuts between the two nodes.

\section{Results and Discussion}

\subsection{Results and Discussion of Density-Comprehensive Index}

The whole networks of the six models are shown in Figures 1-6. On this basis, Equation (1) was used to calculate the network scale and density-comprehensive index of the six models, as shown in Table 2.

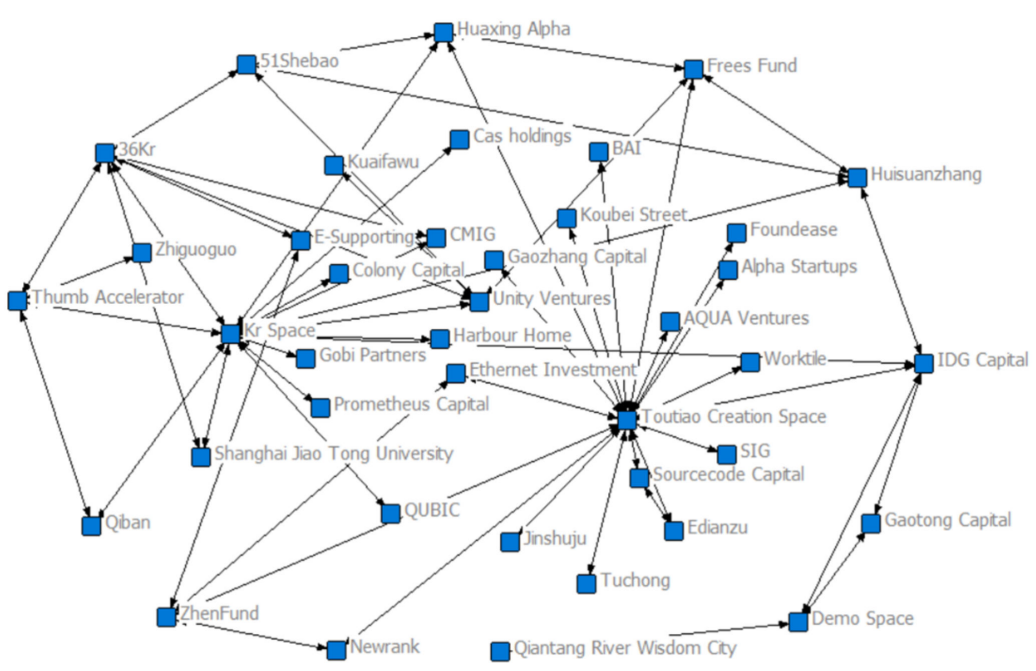

Figure 1. Network media-platform model of China's coworking industry. 


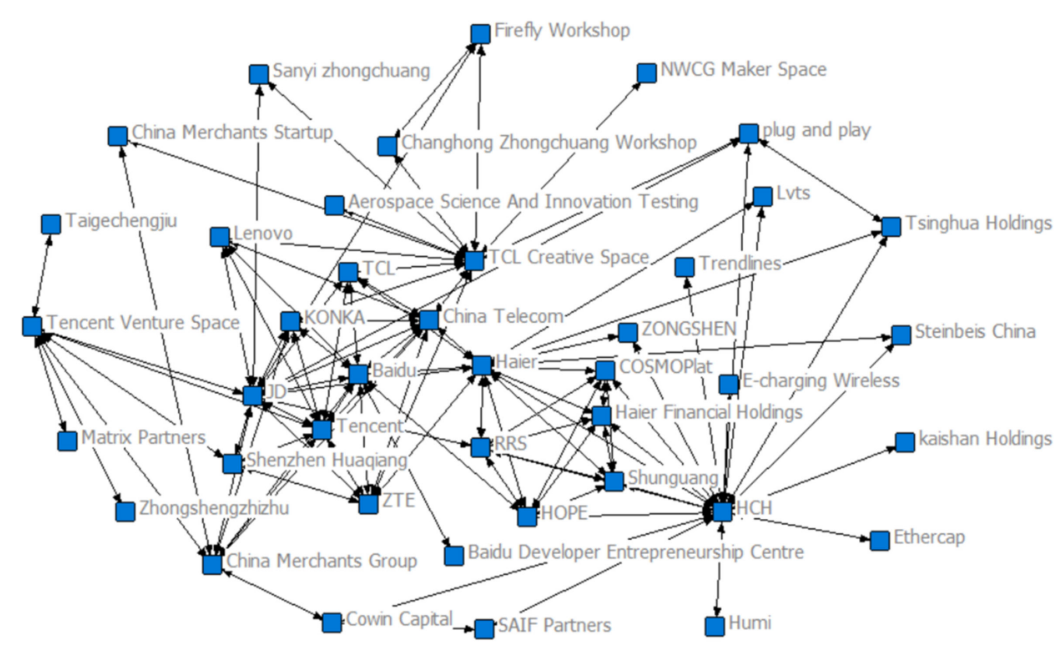

Figure 2. Network of large-leading-enterprise model of China's coworking industry.

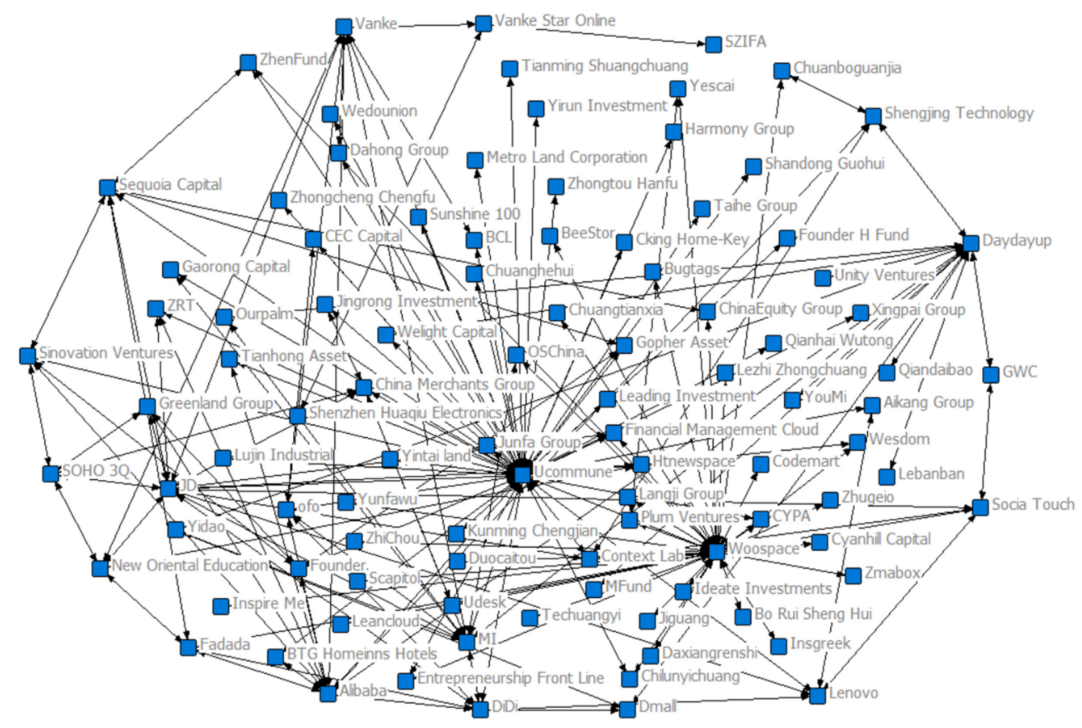

Figure 3. Network of new real-estate model of China's coworking industry.

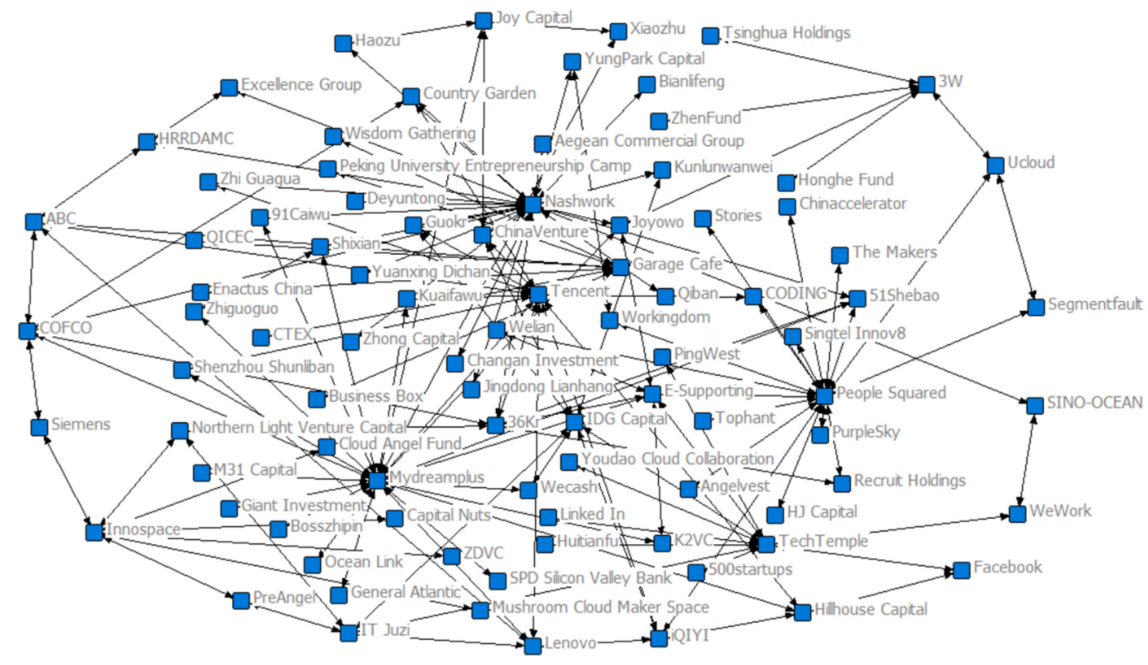

Figure 4. Network of open-space model of China's coworking industry. 


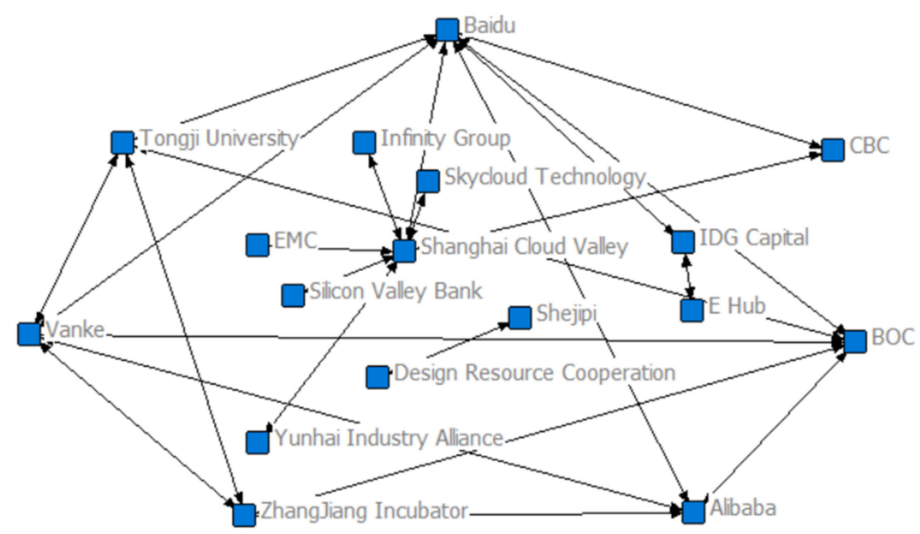

Figure 5. Network of industry-driven model of China's coworking industry.

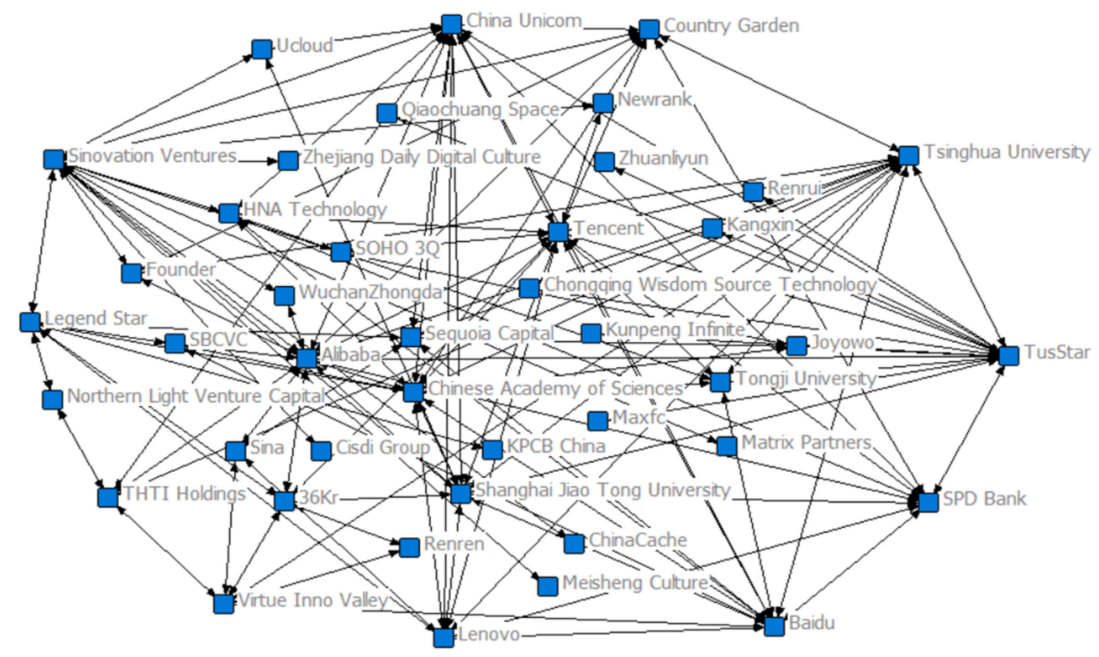

Figure 6. Network of angel-investment model of China's coworking industry.

Table 2. Comparison of density-comprehensive index of six models.

\begin{tabular}{cccccccc}
\hline \multirow{2}{*}{ Model } & & $\begin{array}{c}\text { Media } \\
\text { Platform }\end{array}$ & $\begin{array}{c}\text { Large Leading } \\
\text { Enterprise }\end{array}$ & $\begin{array}{c}\text { New Real } \\
\text { Estate }\end{array}$ & Open Space & $\begin{array}{c}\text { Industry- } \\
\text { Driven }\end{array}$ & $\begin{array}{c}\text { Angel } \\
\text { Investment }\end{array}$ \\
\hline \multirow{2}{*}{ Scale } & Nodes & 40 & 41 & 98 & 89 & 17 & 42 \\
\cline { 2 - 9 } & Lines & 114 & 204 & 336 & 274 & 48 & 238 \\
\hline \multicolumn{2}{c}{ Degree } & 0.0731 & 0.1244 & 0.0353 & 0.035 & 0.1765 & 0.1382 \\
\hline \multicolumn{2}{c}{ Graph centrality } & 0.4089 & 0.3423 & 0.4901 & 0.2432 & 0.2958 & 0.2646 \\
\hline \multicolumn{2}{c}{ Density comprehensive index } & 0.1627 & 0.1905 & 0.1501 & 0.0895 & 0.2238 & 0.1833 \\
\hline
\end{tabular}

Figures 1-6 and Table 2 show that:

1. From the perspective of network scale, the new real-estate and open-space models had the most network nodes and connections, indicating that these two models are relatively mature. The scale of the industry-driven model, on the other hand, was the smallest and lagged far behind the other models, indicating that the development of this model is still in its infancy. The network scales of the media-platform, largeleading-enterprise, and angel-investment models were similar in the middle level among the six models.

2. From the perspective of the density-comprehensive index, the industry-driven model with the smallest scale had the largest density-comprehensive index, while the openspace and new real-estate models with the largest scale had the lowest densitycomprehensive index, which shows that, although the industry-driven model was in 
its infancy, it had significant advantages in building a good industrial ecology, and providing resource support for office enterprises and incubated enterprises. On the other hand, although the network scales of the open-space and new real-estate models were large, it is urgent to promote high-quality development because the two models only provide coworking office spaces and lack professional entrepreneurial services. Therefore, the two models need to be continuously deepened in resource integration, industry cross-border collaboration, and the formation of close cooperation networks.

\subsection{Results and Discussion of Subgroup-Comprehensive Index}

As China's coworking industry has significant characteristics of industrial convergence, the six models formed different types of subgroup clustering, which are called communities here to highlight collaborations within subgroups. The subgroup comprehensive index can be calculated by Equation (2), as shown in Table 3 .

Table 3. Comparison of subgroup comprehensive index of six models.

\begin{tabular}{lcccccc}
\hline & Media Platform & $\begin{array}{c}\text { Large Leading } \\
\text { Enterprise }\end{array}$ & New Real Estate & Open Space & Industry-Driven & Angel Investment \\
\hline$E-I$ Index & -0.789 & -0.157 & -0.417 & -0.372 & -0.833 & 0.261 \\
\hline
\end{tabular}

Table 3 shows that:

(1) Most E-I indices of the six models were negative, indicating that the phenomenon of subgroup was very significant, especially the industry-driven and media-platform models, of which the $E-I$ indices highly tended to be 1 , which means that the leading enterprises were playing a leading role, and other nodes had strong reliance on them. In addition, cooperation mostly occurred within subgroups, and the network was weak in openness, so it is urgent to expand and cultivate cooperation among subgroups.

(2) The angel-investment model was the only one with a positive $E-I$ index, which indicates that the status of enterprises was relatively equal, and cooperation within and between communities was relatively balanced. Low industrial concentration and the urgent need to cultivate leading enterprises are key problems hindering the rapid development of this model.

\subsubsection{Subgroup Analysis of Media-Platform Model}

The media-platform model formed two communities with the same nature, the Krypton space and Toutiao creation space communities, whose leading enterprises are coworking enterprises, as shown in Table 4 and Figure 7.

Table 4. Communities of media-platform model.

\begin{tabular}{|c|c|c|c|c|c|c|c|c|}
\hline Community & Scale & $\begin{array}{c}\text { Diversity } \\
\text { (Number of } \\
\text { Enterprise } \\
\text { Types) }\end{array}$ & $\begin{array}{l}\text { Coworking } \\
\text { Enterprises }\end{array}$ & $\begin{array}{c}\text { Investment } \\
\text { and Financial } \\
\text { Institution }\end{array}$ & $\begin{array}{c}\text { Internet } \\
\text { Enterprise }\end{array}$ & $\begin{array}{l}\text { Real-Estate } \\
\text { Enterprise }\end{array}$ & Universities & $E-I$ Index \\
\hline Kr Space & 23 nodes & 5 types & 3 nodes & 9 nodes & 8 nodes & 2 ndes & 1 node & -0.829 \\
\hline $\begin{array}{c}\text { Toutiao } \\
\text { Creation Space }\end{array}$ & 17 nodes & 3 types & 1 node & 9 nodes & 7 nodes & - & - & -0.727 \\
\hline
\end{tabular}




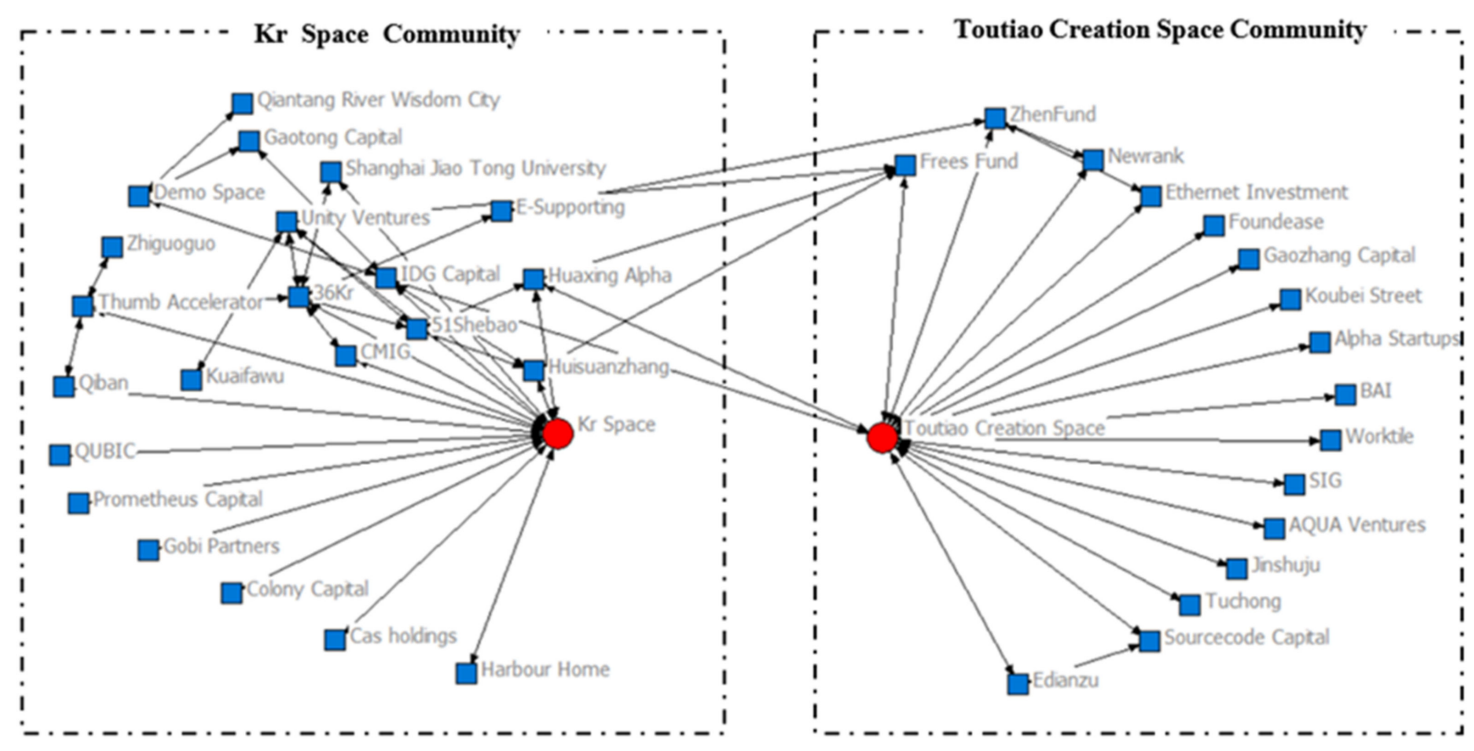

Figure 7. Communities of media-platform model.

Table 4 and Figure 7 show that:

(1) The scale of the two communities was similar, but the Kr Space community had better industrial ecological diversity with five types of enterprises and organizations, namely, coworking enterprise, investment and financial institutions, Internet enterprises, realestate enterprises, and universities.

(2) The E-I indices of the two communities were both negative and highly close to -1 , indicating that the two communities had a high degree of an independent governance faction and a significant characteristic of duopoly. Cooperation between the two communities was weak.

(3) Qualcomm Venture Capital and IDG Capital were the bridges connecting the relationship between the two communities, which is a typical Simmel connection, indicating that investment and financing institutions are playing a crucial role in the development of the media-platform model.

\subsubsection{Subgroup Analysis of Large-Leading-Enterprise Model}

The large-leading-enterprise model formed five communities with different natures: the $\mathrm{HCH}$, TCL Creative Space, Tencent, JD, and Baidu communities. The leading enterprises of the five communities include coworking and Internet enterprises, as shown in Table 5 and Figure 8.

Table 5. Communities of large-leading-enterprise model.

\begin{tabular}{|c|c|c|c|c|c|c|}
\hline Community & Scale & $\begin{array}{c}\text { Diversity } \\
\text { (Number of Enterprise Types) }\end{array}$ & $\begin{array}{l}\text { Coworking } \\
\text { Enterprises }\end{array}$ & $\begin{array}{c}\text { Investment and } \\
\text { Financial Institution }\end{array}$ & $\begin{array}{c}\text { Internet } \\
\text { Enterprise }\end{array}$ & $E-I$ Index \\
\hline $\mathrm{HCH}$ & 18 nodes & 3 types & 3 nodes & 6 nodes & 9 nodes & -0.762 \\
\hline TCL Creative Space & 9 nodes & 2 types & 4 nodes & - & 5 nodes & 0.100 \\
\hline Tencent & 6 nodes & 3 types & 1 node & 1 node & 4 nodes & 0.000 \\
\hline $\mathrm{JD}$ & 5 nodes & 2 types & - & 3 nodes & 2 nodes & 0.487 \\
\hline Baidu & 3 nodes & 3 types & 1 node & 1 node & 1 node & 0.529 \\
\hline
\end{tabular}




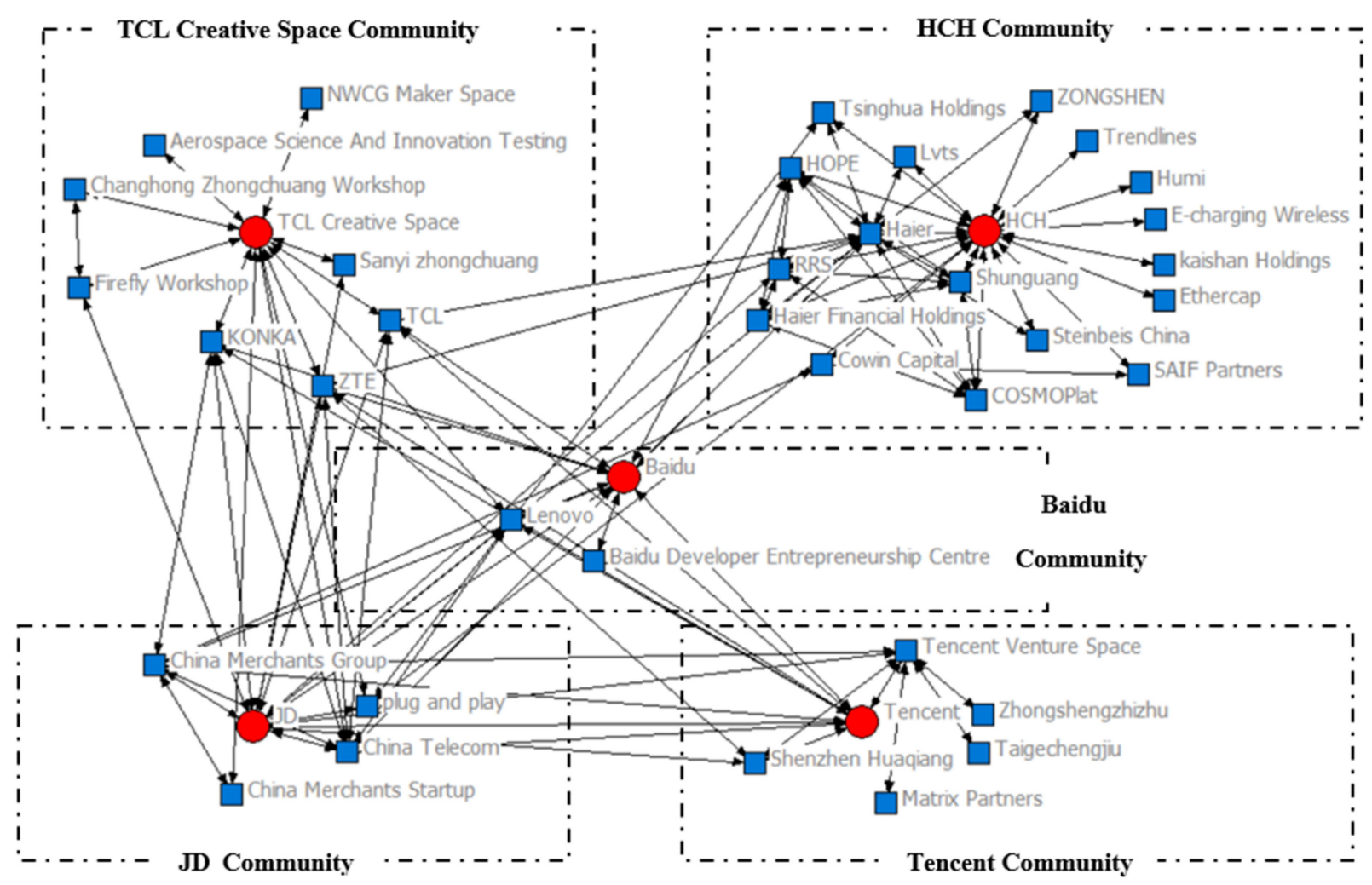

Figure 8. Communities of large-leading-enterprise model.

Table 5 and Figure 8 show that:

(1) The communities of the large-leading-enterprise model presented network characteristics of imbalance. The development of the $\mathrm{HCH}$ community was at a relatively mature stage with strong ecological diversity. The community integrated many resources of the Haier Group, including the Hope R\&D platform, the COSMO design and manufacturing platform, and Gooday sales and logistics channels to achieve comprehensive docking. What is more important is the strong support of financing channels from the Haier Group to comprehensively facilitate the rapid growth of start-ups and office enterprises.

(2) Among the five communities, only the E-I index of $\mathrm{HCH}$ was negative and highly close to -1 , which indicates that the community was relatively weak in openness. This is largely due to the relatively complete industrial chain within the Haier Group. On the other hand, the internal and external cooperation of the four other communities was relatively balanced.

(3) Internet enterprises Baidu and JD Group had network connections with each community, which ensured the overall connectivity of the whole network and had the characteristics of a typical Simmel connection, which plays an important supporting role in promoting the development of this model.

\subsubsection{Subgroup Analysis of New Real-Estate Model}

The new real-estate model formed four communities with different natures, the Ucommune, Woospace, Daydayup, and JD communities. The leading enterprises of the four communities includes coworking and Internet enterprises, as shown in Table 6 and Figure 9. 
Table 6. Communities of new real-estate model.

\begin{tabular}{|c|c|c|c|c|c|c|c|}
\hline Community & Scale & $\begin{array}{c}\text { Diversity } \\
\text { (Number of } \\
\text { Enterprise Types) }\end{array}$ & $\begin{array}{l}\text { Coworking } \\
\text { Enterprises }\end{array}$ & $\begin{array}{c}\text { Investment and } \\
\text { Financial } \\
\text { Institution }\end{array}$ & $\begin{array}{c}\text { Internet } \\
\text { Enterprise }\end{array}$ & $\begin{array}{l}\text { Real-Estate } \\
\text { Enterprise }\end{array}$ & $E-I$ Index \\
\hline Ucommune & 42 nodes & 4 types & 4 nodes & 22 nodes & 7 nodes & 9 nodes & -0.472 \\
\hline Woospace & 35 nodes & 4 types & 1 node & 6 nodes & 27 nodes & 1 node & -0.556 \\
\hline Daydayup & 12 nodes & 3 types & 1 node & 9 nodes & 2 nodes & - & -0.412 \\
\hline JD & 9 nodes & 4 types & 2 nodes & 1 node & 4 nodes & 2 nodes & 0.020 \\
\hline
\end{tabular}

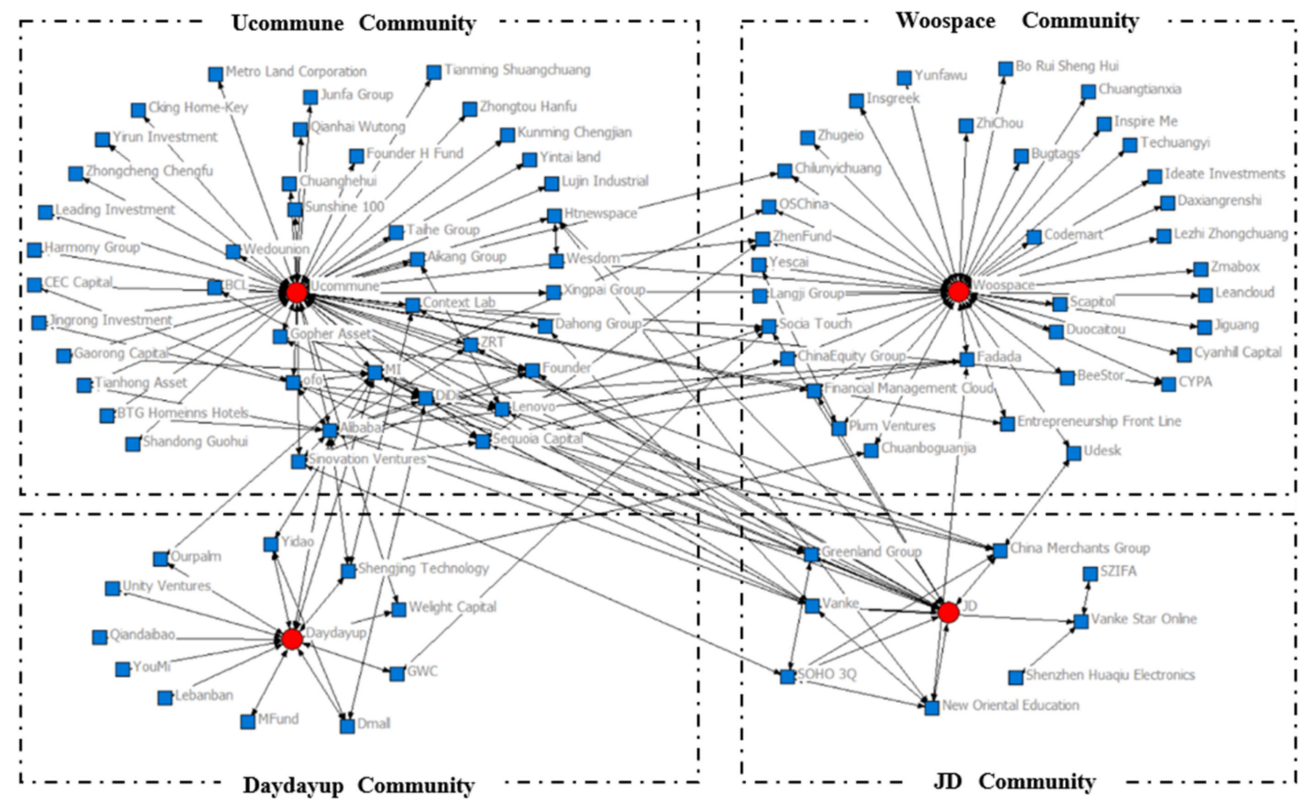

Figure 9. Communities of new real-estate model.

Table 6 and Figure 9 show that:

(1) The number of real-estate enterprises greatly increased compared with other models. The four communities also showed characteristics of imbalance, as the Ucommune and Woospace communities developed on a large scale. The diversity of the Ucommune community was both rich and abundant, which indicates that the Ucommune enterprise had significant advantages in integrating cross-border resources.

(2) Among the four communities, the $E-I$ indices of three communities were negative, but much less than -1 , and the $E-I$ Index of the JD Group community was almost 0 , which indicates that the clique feature of the new real-estate model was somewhat weakened, and openness was very good.

(3) Real-estate enterprise Vanke and Internet enterprise JD Group had the characteristics of a typical Simmel connection, which plays an important supporting role in promoting the development of this model.

\subsubsection{Subgroup Analysis of Open-Space Model}

The open-space model formed seven communities with the same nature, the Nashwork, Mydreamplus, People Squared, TechTemple, Innospace, Garage Café, and 3W communities. The leading enterprises of all seven communities are coworking enterprises, as shown in Table 7 and Figure 10. 
Table 7. Communities of open-space model.

\begin{tabular}{|c|c|c|c|c|c|c|c|}
\hline Community & Scale & $\begin{array}{c}\text { Diversity } \\
\text { (Number of Enterprise Types) }\end{array}$ & $\begin{array}{l}\text { Coworking } \\
\text { Enterprises }\end{array}$ & $\begin{array}{l}\text { Investment and Financial } \\
\text { Institution }\end{array}$ & $\begin{array}{l}\text { Internet } \\
\text { Enterprise }\end{array}$ & $\begin{array}{l}\text { Real Estate } \\
\text { Enterprise }\end{array}$ & $E-I$ Index \\
\hline Nashwork & 22 nodes & 4 types & 1 node & 8 nodes & 11 nodes & 2 nodes & -0.314 \\
\hline Mydreamplus & 19 nodes & 3 types & 1 node & 11 nodes & 7 nodes & - & -0.350 \\
\hline People Squared & 16 nodes & 3 types & 2 nodes & 5 nodes & 9 nodes & - & -0.488 \\
\hline TechTemple & 11 nodes & 3 types & 2 nodes & 2 nodes & 7 nodes & - & -0.158 \\
\hline Innospace & 8 nodes & 2 types & 2 nodes & 6 nodes & - & - & -0.556 \\
\hline Garage Cafe & 8 nodes & 3 types & 1 node & 1 node & 6 nodes & - & -0.846 \\
\hline $3 \mathrm{~W}$ & 5 nodes & 3 types & 1 node & 3 nodes & 1 node & - & -0.333 \\
\hline
\end{tabular}

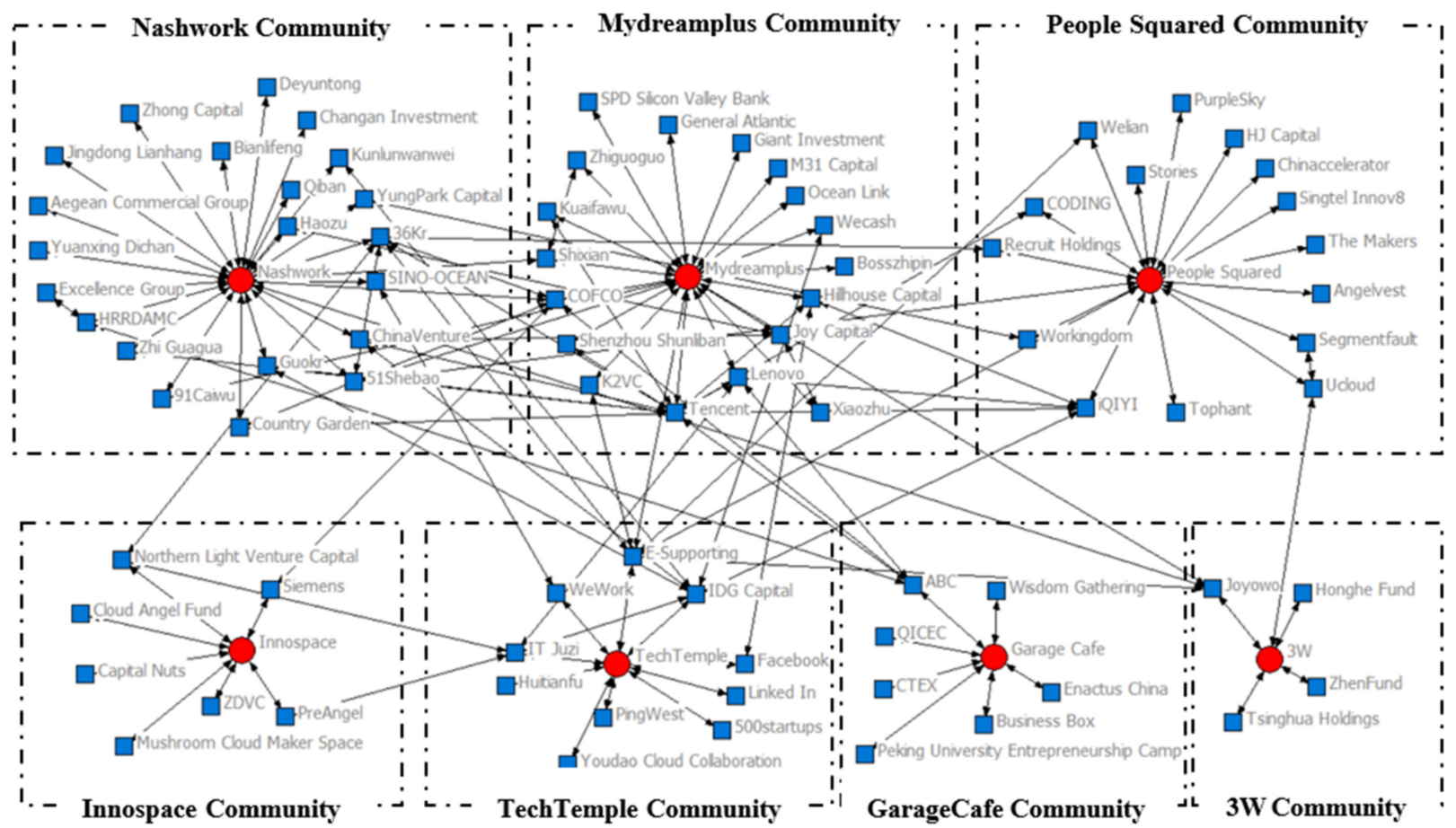

Figure 10. Communities of open-space model.

Table 7 and Figure 10 show that:

(1) The diversity of the open-space model was good, but the imbalance feature was also significant. The Nashwork, Mydreamplus, and People Squared communities were larger in scale. The diversity of the Nashwork community was the most abundant, including investment and financing institutions, real estate, and Internet enterprises, indicating that the Nash Space enterprise had significant advantages in integrating cross-border resources.

(2) The $E-I$ indices of all seven communities were negative, which indicates that the model was also characterized by factions, especially that of the Garage Cafe community, whose index was closest to -1 , which indicates that a self-ecosphere formed inside the community, but openness needs to be improved.

(3) Internet enterprises 51shebao, E-SUPPORTING, Kuaifawu, and investment and financial institution IDG Capital had the characteristics of a typical Simmel connection, which plays an important supporting role in promoting the development of this model.

\subsubsection{Subgroup Analysis of Industry-Driven Model}

The industry-driven model formed three communities with different natures, the Baidu, Shanghai Cloud Valley, and Design Resource Cooperation communities. The leading enterprises of all the three communities are coworking and Internet enterprises, as shown in Table 8 and Figure 11. 
Table 8. Communities of industry-driven model.

\begin{tabular}{|c|c|c|c|c|c|c|c|c|}
\hline Community & Scale & $\begin{array}{c}\text { Diversity } \\
\text { (Number of Enterprise } \\
\text { Types) }\end{array}$ & $\begin{array}{l}\text { Coworking } \\
\text { Enterprises }\end{array}$ & $\begin{array}{c}\text { Investment and } \\
\text { Financial } \\
\text { Institution }\end{array}$ & $\begin{array}{l}\text { Internet } \\
\text { Enterprise }\end{array}$ & $\begin{array}{c}\text { Real-Estate } \\
\text { Enterprise }\end{array}$ & University & $E-I$ Index \\
\hline \multirow{2}{*}{$\begin{array}{c}\text { Baidu } \\
\text { Shanghai Cloud } \\
\text { Valley }\end{array}$} & 8 nodes & 5 types & 2 nodes & 2 nodes & 2 nodes & 1 node & 1 node & -0.875 \\
\hline & 7 nodes & 3 types & 1 node & 3 nodes & 3 nodes & - & - & -0.714 \\
\hline $\begin{array}{c}\text { Design Resource } \\
\text { Cooperation }\end{array}$ & 2 nodes & 2 types & 1 node & - & 1 node & - & - & -1.000 \\
\hline
\end{tabular}

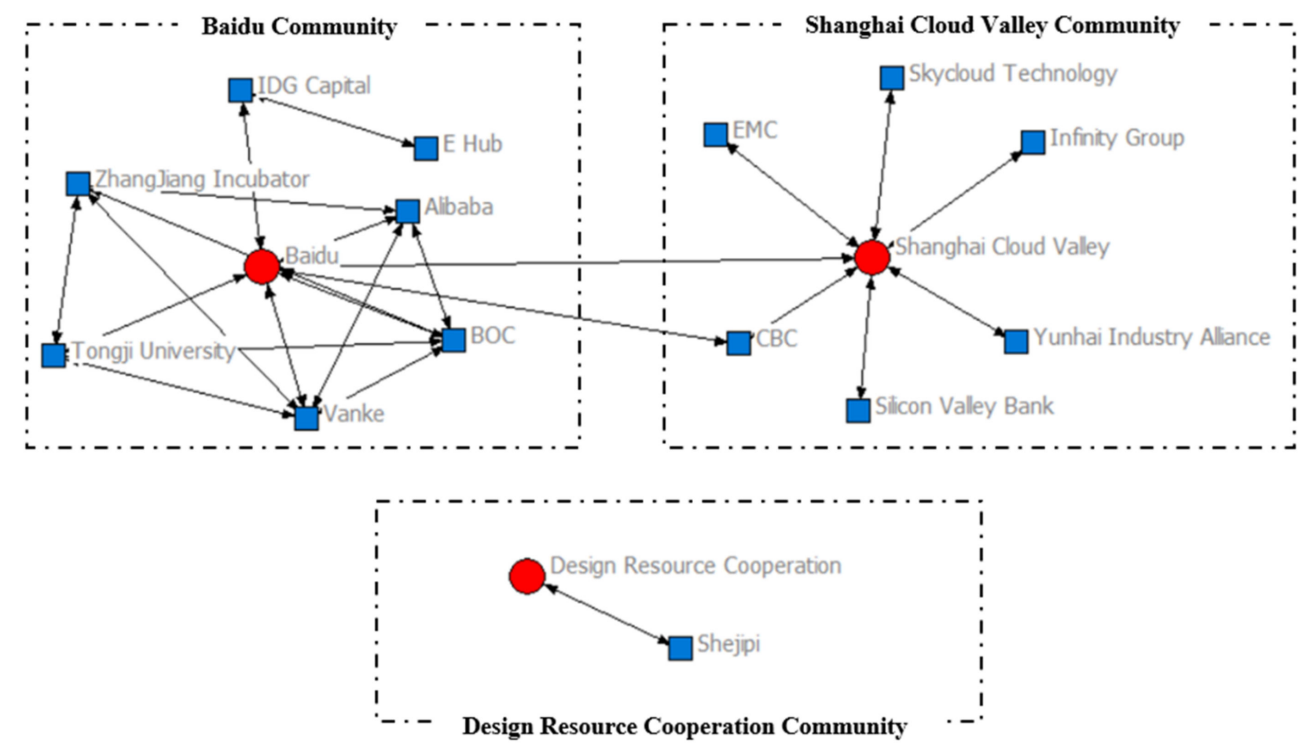

Figure 11. Communities of industry-driven model.

Table 8 and Figure 11 show that:

(1) All three communities were very small, especially the Design Resource Cooperation community, which had no network contact with the other two communities, resulting in the destruction of the connectivity of the overall network. The industry-driven model was the only disconnected network among the six models.

(2) The $E-I$ indices of all three communities were negative and highly close to -1 , indicating that the three communities were independent, and the faction degree was very high.

(3) Because network connectivity was disrupted, the Simmel connection point did not exist. However, for the Baidu and Shanghai Cloud Valley communities, CBC was the bridge of the two communities, indicating that the investment and financing institution has been playing an important role in the development of the two communities.

\subsubsection{Subgroup Analysis of Angel-Investment Model}

The angel-investment model formed six communities with different natures, the Sinovation Ventures, TusStar, Alibaba, Lenovo, University, and Virtue Inno Valley communities. The leading enterprises of all six communities are coworking enterprises and universities, as shown in Table 9 and Figure 12. 
Table 9. Communities of angel-investment model.

\begin{tabular}{|c|c|c|c|c|c|c|c|c|}
\hline Community & Scale & $\begin{array}{c}\text { Diversity } \\
\text { (Number of Enterprise } \\
\text { Types) }\end{array}$ & $\begin{array}{l}\text { Coworking } \\
\text { Enterprises }\end{array}$ & $\begin{array}{c}\text { Investment } \\
\text { and Financial } \\
\text { Institution }\end{array}$ & $\begin{array}{c}\text { Internet } \\
\text { Enterprise }\end{array}$ & $\begin{array}{l}\text { Real-Estate } \\
\text { Enterprise }\end{array}$ & University & $E-I$ Index \\
\hline $\begin{array}{l}\text { Sinovation } \\
\text { Ventures }\end{array}$ & 13 nodes & 4 types & 3 nodes & 3 nodes & 6 nodes & 1 node & - & -0.040 \\
\hline TusStar & 9 nodes & 2 types & 2 nodes & - & 7 nodes & - & - & -0.231 \\
\hline Alibaba & 6 nodes & 2 types & - & 1 node & 5 nodes & - & - & 0.420 \\
\hline Lenovo & 7 nodes & 3 types & 1 node & 5 nodes & 1 node & - & - & 0.333 \\
\hline University & 4 nodes & 1 type & - & - & - & - & 4 nodes & 0.545 \\
\hline Virtue Inno Valley & 3 nodes & 3 types & 1 node & 1 node & 1 node & - & - & 0.385 \\
\hline
\end{tabular}

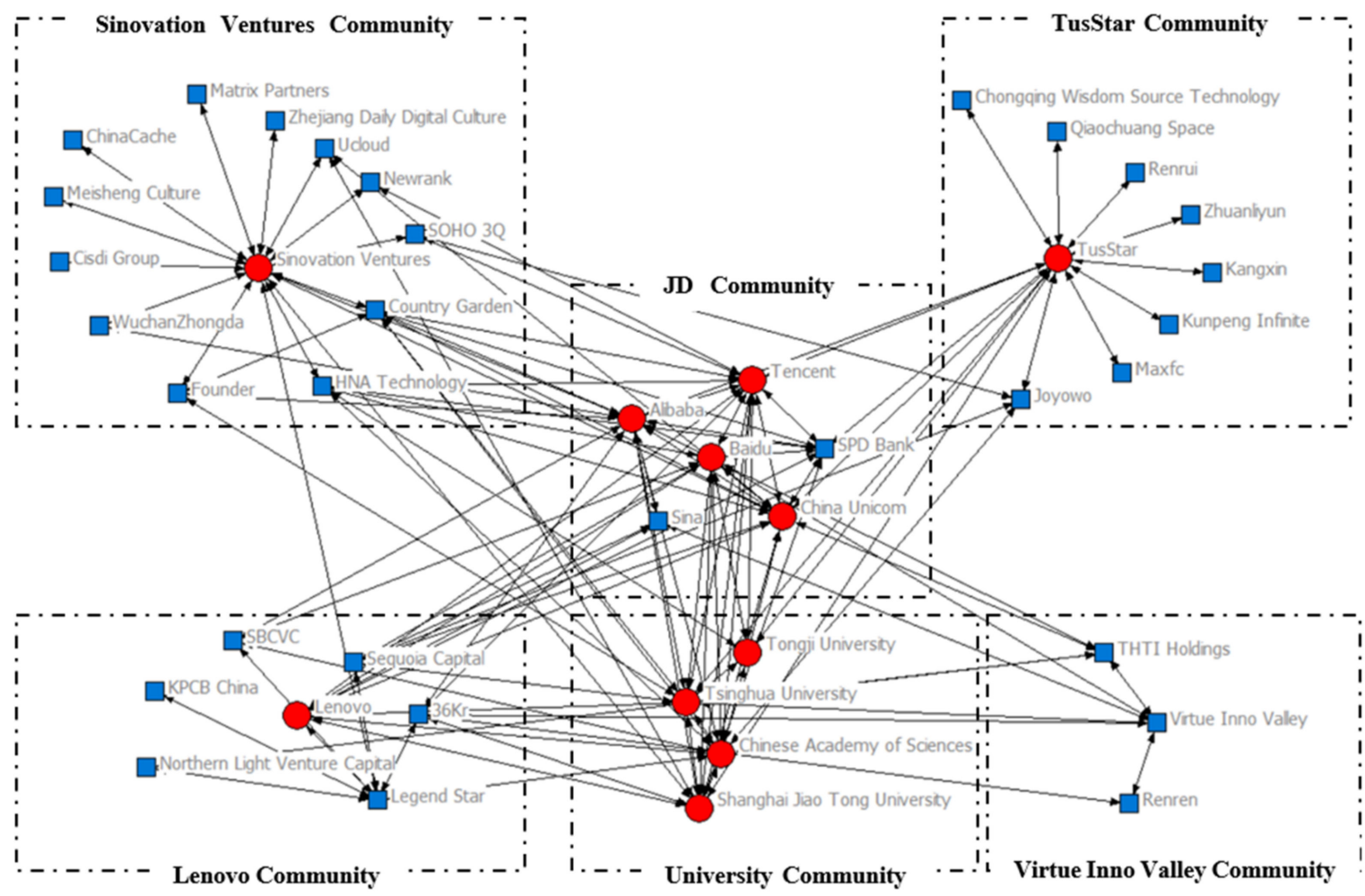

Figure 12. Communities of angel-investment model.

Table 9 and Figure 12 show that:

(1) The scales of six communities were all smaller but more balanced compared to those of the other models. The University community appeared for the first time as the TusStar Incubator, initiated by the Tsinghua Science Park, which is a research cooperation platform that integrates the industry with the scientific and technological innovation resources of universities.

(2) The $E-I$ indices of four communities were positive, while the $E-I$ indices of the Sinovation Ventures and TusStar communities with a larger scale were negative. However, the negative $E-I$ indices tended to be zero, suggesting that the openness of each community was good, and the cooperation between and within communities was sufficient.

(3) Universities such as Shanghai Jiao Tong University, Internet enterprises such as Alibaba and Tencent, real-estate enterprises such as Country Garden, and investment and financing institutions such as SPD Bank were typical Simmel connections, which indicates that the angel-investment model had a relatively rich industrial ecology, and good industrial integration and coordination among different enterprises and organizations. 


\subsection{Results and Discussion of Centrality-Comprehensive Index}

Using Formula (3), we can calculate the centrality-comprehensive index of each node in the six models of China's coworking industry. The top five nodes of the centralitycomprehensive index of each model are arranged in descending order in Table 10.

Table 10. Top five nodes of centrality-comprehensive index of six models.

\begin{tabular}{|c|c|c|c|c|c|c|}
\hline Rank & Media Platform & $\begin{array}{l}\text { Large Leading } \\
\text { Enterprise }\end{array}$ & New Real Estate & Open Space & Industry-Driven & Angel Investment \\
\hline 1 & $\begin{array}{c}\text { Toutiao Creation } \\
\text { Space } \\
(0.999)\end{array}$ & $\begin{array}{c}\mathrm{HCH} \\
(0.931)\end{array}$ & $\begin{array}{l}\text { Ucommune } \\
\quad(0.999)\end{array}$ & $\begin{array}{l}\text { Nashwork } \\
(0.979)\end{array}$ & $\begin{array}{l}\text { Baidu } \\
(0.999)\end{array}$ & $\begin{array}{l}\text { TusStar } \\
(0.895)\end{array}$ \\
\hline 2 & $\begin{array}{c}\text { Kr Space } \\
(0.838)\end{array}$ & $\begin{array}{c}\text { JD } \\
(0.859)\end{array}$ & $\begin{array}{l}\text { Woospace } \\
(0.735)\end{array}$ & $\begin{array}{l}\text { Mydreamplus } \\
\quad(0.928)\end{array}$ & $\begin{array}{c}\text { Shanghai Cloud } \\
\text { Valley } \\
(0.961)\end{array}$ & $\begin{array}{c}\text { Sinovation Ventures } \\
(0.895)\end{array}$ \\
\hline 3 & $\begin{array}{l}\text { IDG Capital } \\
\quad(0.558)\end{array}$ & $\begin{array}{l}\text { Haier } \\
(0.858)\end{array}$ & $\begin{array}{c}\text { JD } \\
(0.302)\end{array}$ & $\begin{array}{c}\text { People Squared } \\
(0.734)\end{array}$ & $\begin{array}{c}\text { BOC } \\
\text { Vanke } \\
(0.517)\end{array}$ & $\begin{array}{c}\text { Alibaba } \\
(0.802)\end{array}$ \\
\hline 4 & $\begin{array}{l}\text { Huaxing Alpha } \\
(0.429)\end{array}$ & $\begin{array}{l}\text { TCL Creative } \\
\text { Space } \\
(0.584)\end{array}$ & $\begin{array}{l}\text { Alibaba } \\
(0.300)\end{array}$ & $\begin{array}{l}\text { Tencent } \\
(0.592)\end{array}$ & $\begin{array}{c}\text { Tongji University } \\
\text { Alibaba } \\
(0.454)\end{array}$ & $\begin{array}{c}\text { China Unicom } \\
(0.694)\end{array}$ \\
\hline 5 & $\begin{array}{l}\text { Unity Ventures } \\
\text { (0.318) }\end{array}$ & $\begin{array}{l}\text { Baidu } \\
(0.546)\end{array}$ & $\begin{array}{c}\text { MI } \\
(0.296)\end{array}$ & $\begin{array}{c}\text { E-Supporting } \\
(0.536)\end{array}$ & $\begin{array}{c}\text { ZhangJiang Incubator } \\
(0.397)\end{array}$ & $\begin{array}{l}\text { Tencent } \\
(0.669)\end{array}$ \\
\hline
\end{tabular}

Table 10 shows that:

(1) The top five nodes of six models include coworking, Internet, real-estate, and investment and financing enterprises, and universities, which also verifies that the ecological diversity of China's coworking industry was good, and cross-border characteristics were very significant.

(2) Among the 28 nodes ranking among the top five, 13 were coworking enterprises, accounting for the largest proportion, and all were incubators or maker space operation enterprises, which fully proves that the integration of China's coworking industry with incubators and maker spaces was very high, so the coworking industry plays an increasingly important role in upgrading China's mass entrepreneurship and innovation.

(3) Internet enterprises JD group, Tencent, and Alibaba ranked in the top five among the six models, which shows that Internet giants both play a very important role in the development of China's coworking industry, and have adopted the strategy of ecological development, especially Alibaba, ranking in the top five models in the new real-estate, angel-investment, and industry-driven models.

(4) The proportion of investment and financing enterprises in the top five nodes was relatively low, and all existed in the media-platform model, which shows that China's coworking industry is relatively less dependent on capital. This is one of the reasons why only the coworking industry sprung up at the turning point of the decline of China's sharing economy after a large amount of capital investment.

On the basis of the measurement of the centrality-comprehensive index, further analysis can be performed by deconstructing the index, as shown in Figures 13-18. Betweenness centrality was the main factor that affected the ranking of the centrality-comprehensive index of most models, including the large-leading-enterprise, new real-estate, angelinvestment, and industry-driven models, which shows that the ability to control resources such as information and capital was the key factor to determine the status and influence of enterprises in these four models. Point centrality was the main factor that affected the centrality-comprehensive index of the open-space and media-platform models, which shows that the number of network relations based on industrial cooperation was the key factor to determine the status and influence of enterprises in the two models. 


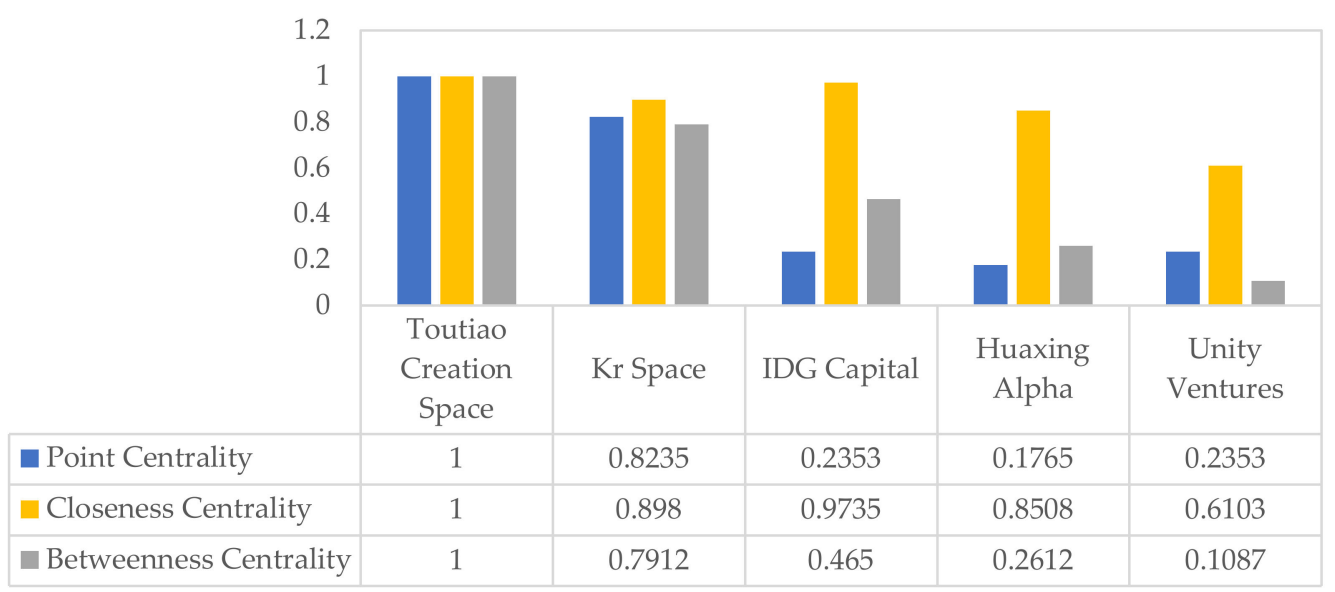

Figure 13. Decomposition of centrality-comprehensive index in media-platform model.

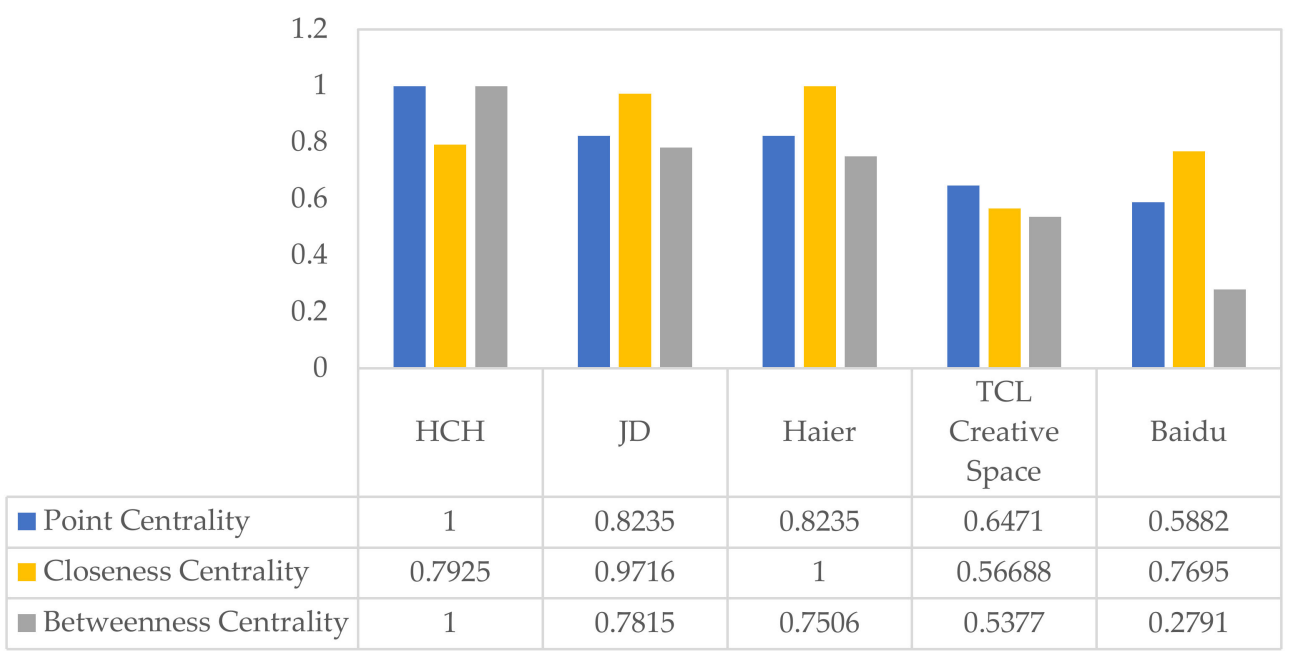

Figure 14. Decomposition of centrality-comprehensive index in large-leading-enterprise model.

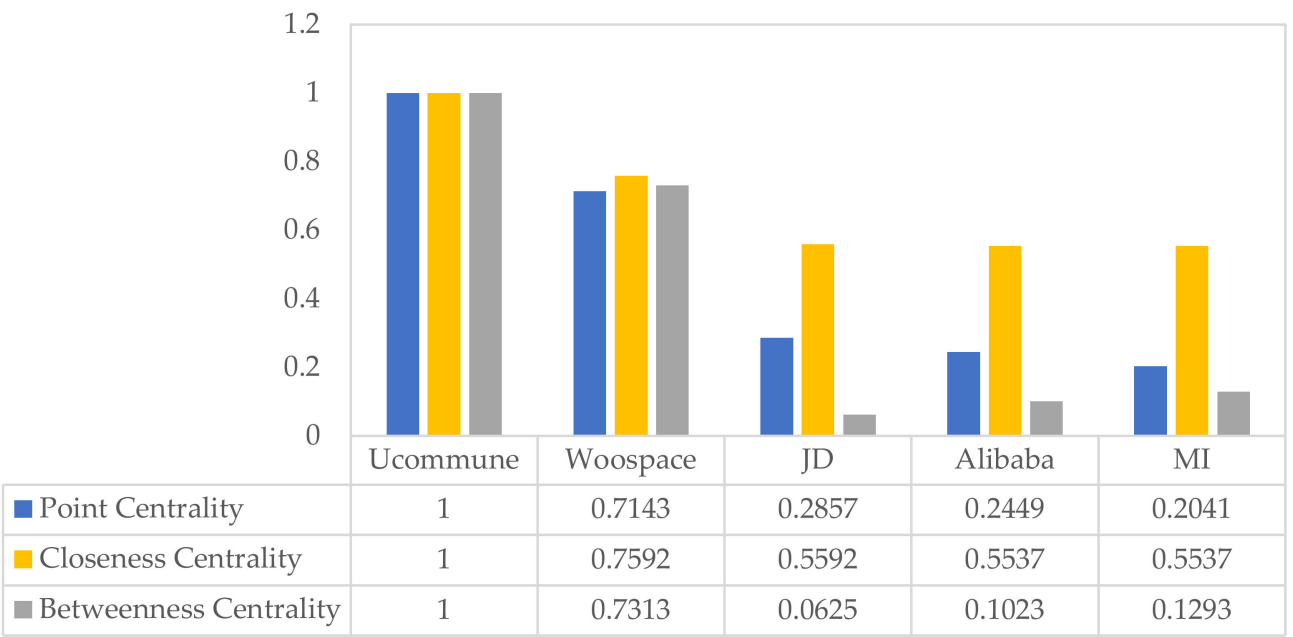

Figure 15. Decomposition of centrality-comprehensive index in new real-estate model. 


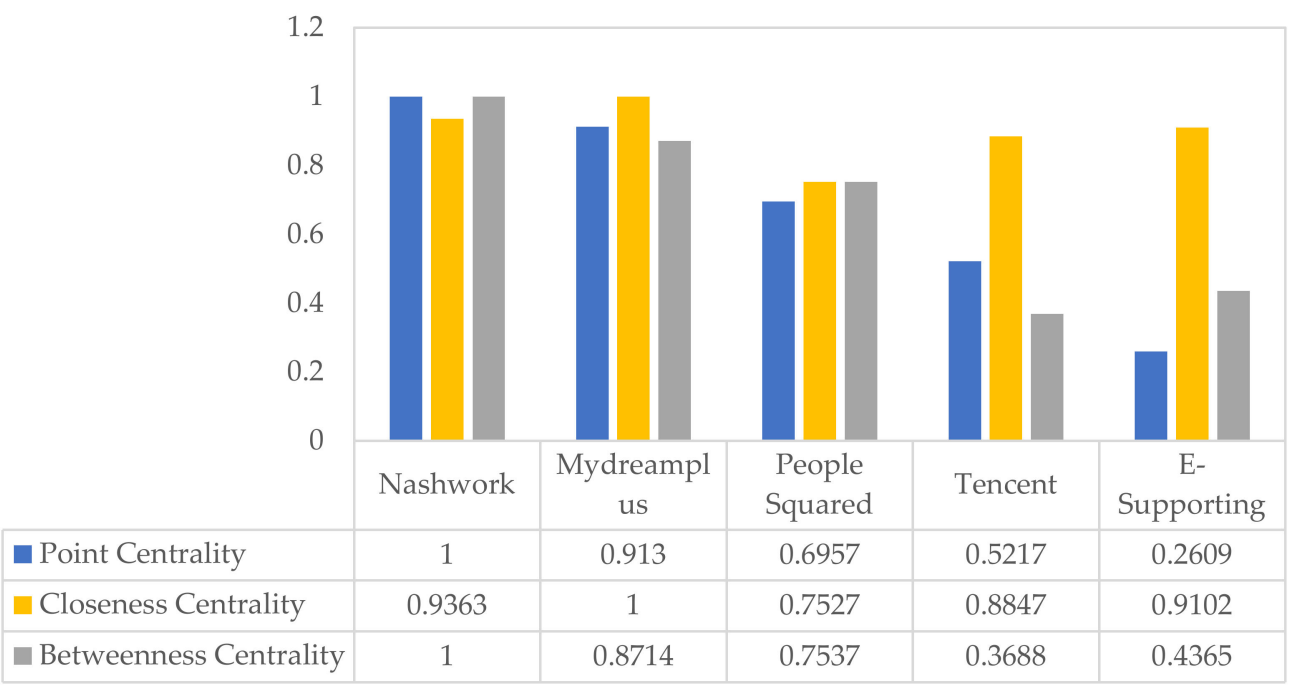

Figure 16. Decomposition of centrality-comprehensive index in open-space model.

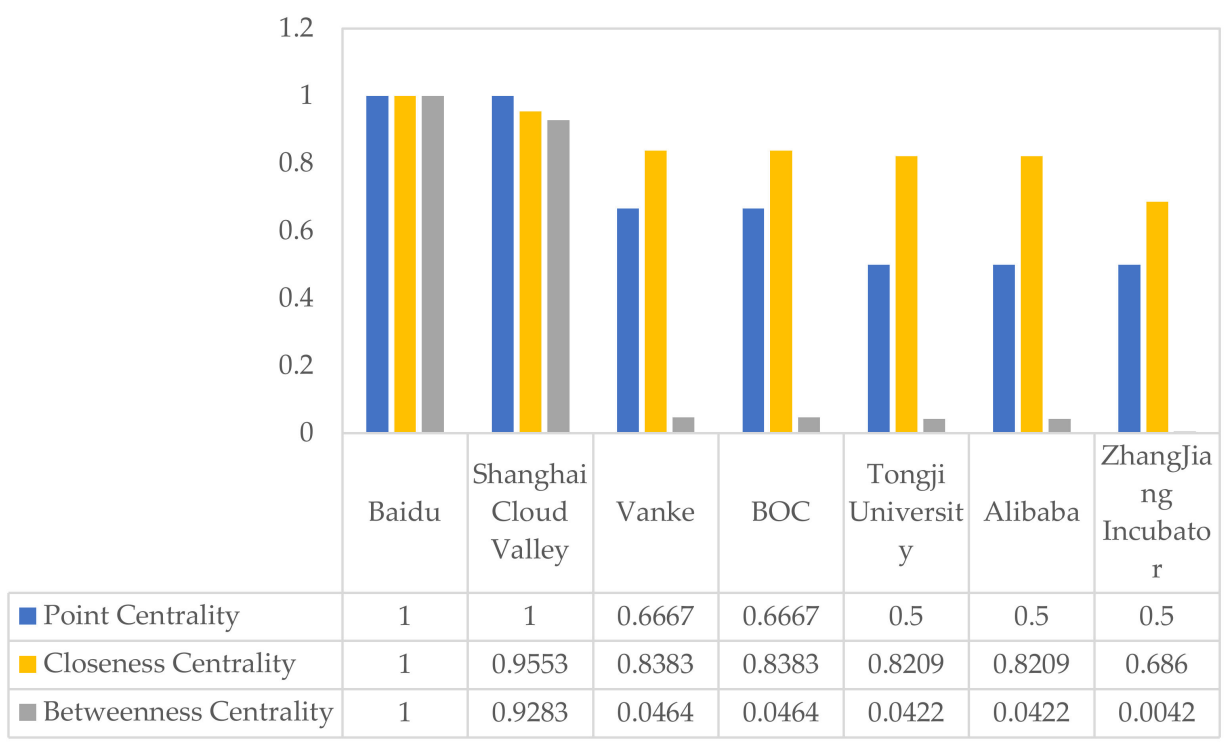

Figure 17. Decomposition of centrality-comprehensive index in industry-driven model.

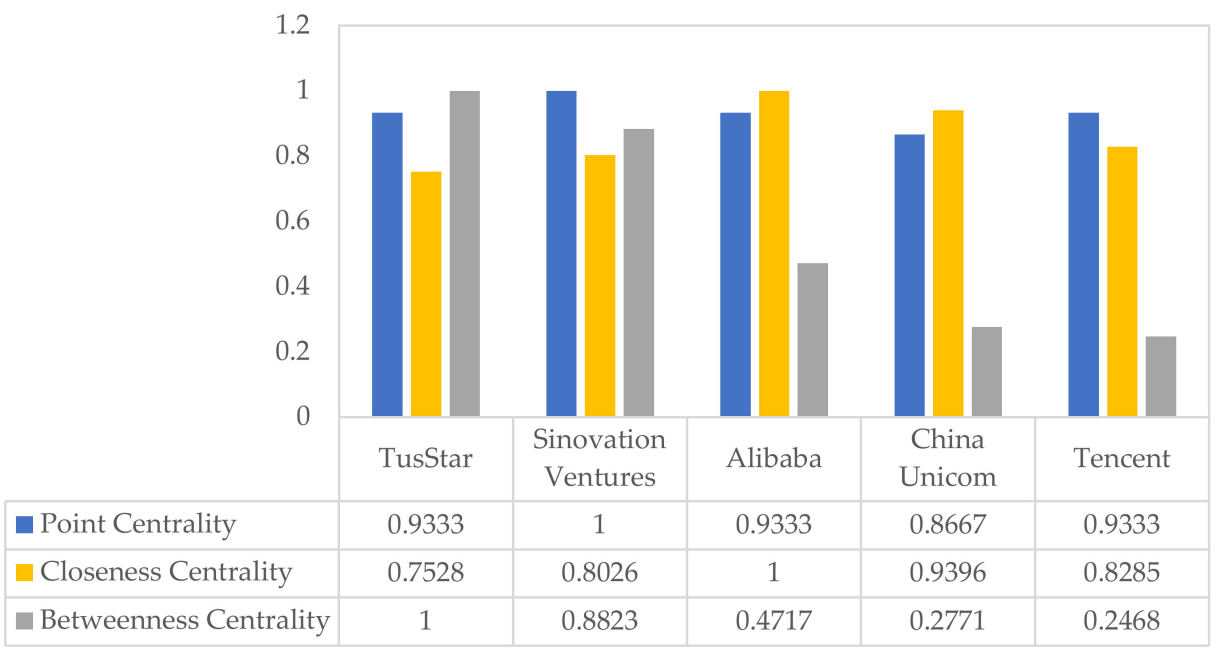

Figure 18. Decomposition of Centrality-comprehensive index in angel-investment model. 


\section{Conclusions and Discussion}

In the transitional period of the sharing-economy industry in China, only the coworking industry maintained relatively rapid growth. In addition, the recently proposed by the Chinese government strategy of upgrading mass entrepreneurship and innovation also brought about huge policy dividends and opportunities to the coworking industry. However, there are several bottlenecks, such as the single-profit model, and the homogenization of products and services. As a research frontier, existing theoretical research lags far behind industrial development. Therefore, different from previous research mostly focusing on the microlevel, such as Youke Workshop, WeWork, and Venture Café, SNA was used here to build a comprehensive index system to achieve the scientific and comprehensive measurement of China's coworking industry from the macro-, meso-, and microlevels. The index was applied to the comparative analysis of six models of the coworking industry from the perspective of network organization. Analytical results indicate that China's coworking industry formed a good ecological network with rich ecological diversity, including coworking, Internet, and real-estate enterprises, investment and financing institutions, and universities, which reflects the trend and characteristics of significant industrial crossborder integration. Simply imitating foreign advanced experience instead of adopting the development path with Chinese characteristics is the key bottleneck restricting the sustainability of the coworking industry. What is different from other countries is that China's coworking industry embodies a profound gene of entrepreneurship and innovation since its early stage of development, and most of the leading enterprises are born out of the incubators and maker space operation agencies [13-19]. The initial goal of the coworking industry represented by the United States and the United Kingdom was to revitalize some old factories, while the original intention of the industry in China was to provide relatively cheap office spaces for entrepreneurs in cities such as Beijing, Shanghai, Shenzhen, and Guangzhou, whose housing and renting prices are very high, so as to reduce the cost of entrepreneurship. In addition, coworking enterprises in Europe and the United States are mainly characterized by renting working stations, while entrepreneurs in China are mostly teams, emphasizing the privacy of work, so independent office spaces are the mainstream trend. Meanwhile, different from European countries and the US, the development of China's coworking industry is supported by entrepreneurship and innovation policies, and there are significant policy dividends behind its rapid development. However, although the development of China's coworking industry is very rapid, the policy and capital-driven characteristics are also a double-edged sword, leading to the brutal and disorderly growth of the industry, which is an obstacle to the formation of a multiple-profit model and the realization of sustainable development. In addition, how to give full play to the platform role of Internet giant enterprises is both in line with the development trend of coworking-industry integration, and can break the development bottleneck of the single-profit model. Internet giant enterprises represented by Alibaba, Tencent, and Baidu play a very important role in the development of China's coworking industry, and all have a strategic layout among several models, which indicates that the ecological development strategy of cross-border integration of Chinese Internet giant enterprises is an inevitable trend.

\subsection{Discussion and Significance}

The coworking industry is a rapidly developing emerging industry in China, and the guidance of existing theoretical research to industrial development is limited. In particular, many studies focus on the case studies of specific coworking enterprises on the microlevel, while the systematic framework on the industrial level is rarely involved, especially scientific measurements on the development level of China's coworking industry. The characteristics of model diversification were also ignored in existing studies. Because of the deficiency of existing studies, a comprehensive index system was constructed on the basis of an SNA perspective to carry out multilevel measurement and systematic analysis on the current situation of China's coworking industry. Moreover, this paper also considered characteristics of model diversification, so as to put forward targeted countermeasures and 
suggestions. In addition, the comprehensive index system has good universality and can be applied to all industries with network organization after moderate adjustment.

On the basis of the above analysis, this paper proposed the following suggestions, aiming to break through the bottleneck and accelerate the sustainable development of the industry.

(1) Supporting and encouraging the development of China's coworking industry, and conducting appropriate supervision. The coworking industry has been faced with a series of challenges since the early stage of development, such as fuzzy industrial boundary, complex environments, and the localization of international business models. Therefore, it is necessary to encourage and support the development of China's coworking industry with an inclusive attitude by ensuring the market-oriented certification of coworking enterprises from legal and institutional aspects, simplifying the approval process, issuing supporting registration implementation rules, and giving fair market competition status. While encouraging development, supervision is also an important guarantee to ensure the sustainable development of the industry. It is also imperative to build a systematic standard from the aspects of property management, securities, and compensation.

(2) Exploring the localization development path of the coworking industry from the perspective of Chinese culture. Most of the coworking industry in Western countries adopted station sharing, represented by WeWork, which is originated from the prevailing sharing culture and relatively mature entrepreneurial atmosphere in European countries and the US. However, China's innovation culture is mostly based on teams, which has more obvious boundary awareness and the need for private offices. Therefore, it is necessary to explore the development path with Chinese characteristics on the premise of fully comparing the cultural differences between China and other countries. For example, China's coworking industry should strengthen social functions and enhance the stickiness of community, and actively promote upgrading and transforming from "coworking" to "coliving".

(3) Formulating targeted industrial policies according to the development stages and characteristics of different development models. For example, in terms of the largeleading-enterprise model, how to guide leading enterprises, especially advanced manufacturing enterprises, to cross the boundary into the coworking industry is an important engine to realize the convergence of the manufacturing and service industries.

(4) Improving industrial concentration and speeding up the cultivation of leading enterprises. In the boom of mass entrepreneurship and innovation, with a sharp increase in the number of involved enterprises, the trend of mergers and acquisitions is more significant, and the head effect appears. Therefore, enterprises in different development models need to find complementary enterprises for mergers and acquisitions to integrate their advantageous resources. Leading enterprises should actively raise funds, arrange sites, share resources, gather upstream and downstream enterprises, and establish industrial ecological networks to promote the sustainable development of the industry.

\subsection{Limitations and Future Research}

This paper is not without its limitations. For simplicity, this research was based on the supply side without considering the demand side. China's regional imbalance is particularly obvious, so demand based on different regions was not analyzed in this paper. In addition, the comprehensive index system proposed in this paper was only applied to the coworking industry, which needs to be improved in more fields.

Valuable topics remain for future research. First, a predictive demand model for consumers will be studied to analyze the mechanism of the influence from the demand side on the supply side. Second, the comprehensive index system should be applied to other sharing industries for verification and improvement. Lastly, an important future research direction is how to expand the comprehensive-index system for a more scien- 
tific and comprehensive evaluation of industrial development based on more sufficient data collection.

Author Contributions: D.Z. designed the study and wrote the paper. M.Y. and H.W. collected and analyzed the data. W.L. revised the paper. All authors have read and agreed to the published version of the manuscript.

Funding: This research was supported by the National Natural Science Foundation of China (71803073), and the Humanities and Social Sciences Foundation of Chinese Ministry of Education (18YJC790211).

Institutional Review Board Statement: Not applicable.

Informed Consent Statement: Not applicable.

Data Availability Statement: Not applicable.

Acknowledgments: Special thanks to the reviewers for their valuable comments.

Conflicts of Interest: The authors declare no conflict of interest.

\section{References}

1. The State Council. The State Council's Opinions on Several Policy Measures to Vigorously Promote Mass Entrepreneurship and Innovation. Available online: http:/ / www.gov.cn/xinwen/2015-08/05/content_2909039.htm (accessed on 5 August 2015).

2. The State Council. The State Council on Promoting the Development of High-Quality Innovative Undertaking to Build the “Double Gen" Upgrade. Available online: http://www.gov.cn/zhengce/content/2018-09/26/content_5325472.htm?trs=1 (accessed on 26 September 2018).

3. Chase, R. Sharing Economy: Restructure New Business Model; Zhejiang People's Publishing House: Hangzhou, China, 2015.

4. Alraeeini, M.; Zhong, Q.; Antarciuc, E. Analysing drivers and barriers of accommodation sharing in Dubai using the greyDEMATEL approach. Sustainability 2019, 11, 5645. [CrossRef]

5. Zhao, D.; Xue, Y.; Cao, C.; Han, H. Channel selection and pricing decisions considering three charging modes of production capacity sharing platform: A sustainable operations perspective. Sustainability 2019, 11, 5913. [CrossRef]

6. Laurenti, R.; Singh, J.; Cotrim, J.M.; Toni, M.; Sinha, R. Characterizing the sharing economy state of the research: A systematic map. Sustainability 2019, 11, 5729. [CrossRef]

7. Zhang, D.; Shi, Y.; Li, W. China's sharing economy of mobility industry: From perspective of industrial ecosystem. Sustainability 2019, 11, 7130. [CrossRef]

8. Iresearch Market Consulting Co., LTD. Research Report on China Co-Working Industry. 2017. Available online: http://www.19 9it.com/archives/1220145.html (accessed on 17 April 2017).

9. Mao, D.; Gao, D. Hack Away at Corporate Barriers: Co-Working in an Era of Sharing; China Renmin University Press: Beijing, China, 2017.

10. Castilho, M.F.; Quandt, C.O. Collaborative capability in coworking spaces: Convenience sharing or community building? Technol. Innov. Manag. Rev. 2017, 7, 32-42. [CrossRef]

11. Waters-Lynch, J.; Potts, J. The social economy of coworking spaces: A focal point model of coordination. Rev. Soc. Econ. 2017, 75, 417-433. [CrossRef]

12. Gong, F.; Ouyang, H.; Yi, C. Research on business model of shared office space based on sharing economy. Mark. Mod. 2017, 1, 247-248.

13. Zhang, Y.; Mao, J. Research on business Model Innovation and Growth Strategy of Shared Office Space-A case study of Youke Workshop. Sci. Technol. Prog. Policy 2017, 34, 1-8.

14. Yao, Y. WeWork: Sell shared office space as a product. China Small Medium Enterp. 2017, 03, 52-54.

15. Feng, H.; Qu, W. Social network and innovation entrepreneurship of Crowd maker space-Based on case study of startup Café. Sci. Res. Manag. 2019, 40, 168-178.

16. Duan, C.; Jia, W. The operation of shared office space under the sharing economy: A case study of Zhong chuang space in China. Urban Dev. 2018, 06, 74-75.

17. Zhang, J.; Xu, X. Research on the development and optimization of joint office space under the background of sharing economy. Farm Econ. Manag. 2020, 09, 48-50.

18. Berbegal-Mirabent, J. What do we know about co-working spaces? Trends and challenges ahead. Sustainability 2021, $13,1416$. [CrossRef]

19. Wang, C. Rethinking joint office from the source of asset end and service end-Taking You Ke workshop as an example. China Real Estate 2020, 11, 50-53.

20. Wang, Q. An analysis of the teaching reform path of "college students' innovation and entrepreneurship" course based on constructivism theory. J. Chengdu Inst. Technol. 2019, 22, 72-76.

21. Lin, X.; Gao, S.; Liu, X. The basic types, business model and theoretical value of maker space. Stud. Sci. Sci. 2016, 34, 923-929. 
22. Wang, Q. Profit model analysis and optimization suggestions for joint office space. Mod. Bus. Trade Ind. 2019, 40, 48-50.

23. Cao, S.; Yang, C. Research on the operation performance and development of regional maker space-Based on the research of Wuxi joint office maker space. Mark. Wkly. 2020, 33, 22-24.

24. Chen, H. Analysis on the business model and development trend of China's shared office format. Enterp. Reform Manag. 2020, 08, 107-108.

25. Xu, J.; Xu, R.; Zhang, J. Research on the influence mechanism of sharing economy on innovation behavior of small and medium-sized enterprises-Taking Su qian area as an example. Times Financ. 2019, 15, 42-43.

26. Xu, G.; Lin, G. Social networks for public participation in innovation: Maker culture and maker space. Sci. Sci. Manag. S T 2016, $37,11-20$.

27. Cheah, S.; Ho, Y.-P. Co-working and sustainable business model innovation in young firms. Sustainability 2019, 11, 2959. [CrossRef]

28. Feng, H. Strategy analysis of multi-layer capital market to promote the development of science and technology enterprisesTaking Shandong as an example. Times Financ. 2019, 32, 26-28.

29. Okano, M.T. Interorganisational networks and social innovation: A study in milk production chain. Int. J. Innov. Sustain. Dev. 2017, 11, 317-335. [CrossRef]

30. Hamari, J. The Sharing economy: Why people participate in collaborative consumption. J. Assoc. Inf. Sci. Technol. 2016, 67, 2047-2059. [CrossRef]

31. Rong, C.H. Analysis on the relationship between material, credit and time-space economy of internet sharing mobility. Manag. World 2018, 4, 101-112.

32. Choi, J.W.; Kim, H.Y. Preparation of study on social network analysis in the sharing economy of tourism field. Indian J. Public Health Res. Dev. 2018, 9, 981-985. [CrossRef]

33. Lee, J.H.; Choi, J.W.; Kim, K.Y. Segmenting Korean millennial consumers of sharing economy services on social networking: A psychographic-based approach. J. Internet Comput. Serv. 2015, 16, 109-121.

34. Martin, P.F.; Florian, U.; Gohar, F.K.; Marko, S.; Andy, N.; Tobias, S. From goods to services consumption: A social network analysis on sharing economy and servitization research. J. Serv. Manag. Res. 2018, 2, 3-16.

35. Gao, S.Y.; Zhang, Y.; Liu, H.B. Social network analysis to the value creation of sharing economy business model. J. Tech. Econ. Manag. 2019, 7, 79-84.

36. Chen, Y.; Liu, F.Z.; Wu, J. Studying users' interaction behaviors of sharing economic platform with 2-mode complex network analysis. Data Anal. Knowl. Discov. 2017, 1, 72-82.

37. Luo, J.D. Social Network Analysis; Social Sciences Academic Press: Beijing, China, 2015.

38. China Business Industry Research Institute. A Research Report on the Development Prospect of China's Shared Office Industry. 2018. Available online: https:/ /www.askci.com/news/chanye/20180817/1535581129232.shtml (accessed on 17 August 2018).

39. Ai Media Life and Travel Industry Research Center. Sharing Economy Industry Panorama Research Report (2018-2019). 2019. Available online: https:/ / www.iimedia.cn/c400/66502.html (accessed on 24 October 2019).

40. Johnson, S.E. Ecosystem Ecology; Science Press: Beijing, China, 2018.

41. Michael, B.; Colin, R.; John, L. Ecology: From Individual to Ecosystem, 4th ed.; Higher Education Press: Beijing, China, 2016.

42. Zhao, D.Z.; Li, G. Development from network organization to business ecosystems. Ind. Eng. J. 2005, 1, 24-28.

43. Shi, L.; Chen, W.Q.A. Industrial ecology in China: Retrospect and prospect. Acta Ecol. Sin. 2016, 36, 7158-7167.

44. Liu, L.D. Internet Ecosystem; China Zhigong Publishing House: Beijing, China, 2018.

45. Moore, J.F. Predators and prey: A new ecology of competition. Harv. Bus. Rev. 1993, 71, 75-83. [PubMed]

46. Li, Q.; Jie, X.W. The value evaluation study of keystone corporation business ecosystem based on analysis of comparation between Huawei and ZTE. Sci. Technol. Prog. Policy 2012, 29, 110-114.

47. Paul, H. The Ecology of Commerce; Shanghai Translation Publishing: Shanghai, China, 2001.

48. Zhang, Z.; Wang, F.Y.; Zhang, Y.M. Cloud innovation and construction of internet finance ecosystem: Case study of Ali Fin-Cloud. Res. Econ. Manag. 2017, 38, 53-60.

49. Yi, P.-T.; Li, W.-W. Induced cluster-based OWA operators with reliability measures and the application in group decision-making. Int. J. Intell. Syst. 2019, 34, 527-540. [CrossRef]

50. Chen, Z.; Liu, S.; Wu, H.; Tang, G. Research on the rise of innovation space, innovation city leading and global innovation driven development differential pattern. Econ. Geogr. 2017, 37, 23\#x2013;31+39.

51. Luo, M.; Li, L.Y. Innovation of business model in internet era: From value creation perspective. China Ind. Econ. 2015, 1, 95-107.

52. Insights. Investment Potential Analysis and Future Prospect Forecast Report of China's Shared Office Industry (2019-2025). 2019. Available online: https:/ / www.chyxx.com/research/201905/736814.html (accessed on 22 October 2019). 